\title{
Comparing different generations of idealized solar geoengineering simulations in the Geoengineering Model Intercomparison Project (GeoMIP)
}

\author{
Ben Kravitz ${ }^{1,2}$, Douglas G. MacMartin ${ }^{3}$, Daniele Visioni ${ }^{3}$, Olivier Boucher ${ }^{4}$, Jason N. S. Cole ${ }^{5}$, Jim Haywood Ha, $^{6,7}$ \\ Andy Jones ${ }^{7}$, Thibaut Lurton ${ }^{4}$, Pierre Nabat ${ }^{8}$, Ulrike Niemeier ${ }^{9}$, Alan Robock ${ }^{10}$, Roland Séférian $^{8}$, and \\ Simone Tilmes ${ }^{11}$ \\ ${ }^{1}$ Department of Earth and Atmospheric Sciences, Indiana University, Bloomington, IN, USA \\ ${ }^{2}$ Atmospheric Sciences and Global Change Division, Pacific Northwest National Laboratory, Richland, WA, USA \\ ${ }^{3}$ Sibley School of Mechanical and Aerospace Engineering, Cornell University, Ithaca, NY, USA \\ ${ }^{4}$ Institut Pierre-Simon Laplace (IPSL), Sorbonne Université/CNRS, Paris, France \\ ${ }^{5}$ Environment and Climate Change Canada, Toronto, Ontario, Canada \\ ${ }^{6}$ College of Engineering, Mathematics and Physical Sciences, University of Exeter, Exeter, UK \\ ${ }^{7}$ UK Met Office Hadley Centre, Exeter, UK \\ ${ }^{8}$ CNRM, Université de Toulouse, Météo-France, CNRS, Météo-France, Toulouse, France \\ ${ }^{9}$ Max Planck Institute for Meteorology, Hamburg, Germany \\ ${ }^{10}$ Department of Environmental Sciences, Rutgers University, New Brunswick, NJ, USA \\ ${ }^{11}$ Atmospheric Chemistry Observations and Modeling Laboratory, National Center for Atmospheric Research, \\ Boulder, CO, USA
}

Correspondence: Ben Kravitz (bkravitz@iu.edu)

Received: 17 July 2020 - Discussion started: 28 August 2020

Revised: 4 February 2021 - Accepted: 14 February 2021 - Published: 19 March 2021

\begin{abstract}
Solar geoengineering has been receiving increased attention in recent years as a potential temporary solution to offset global warming. One method of approximating globalscale solar geoengineering in climate models is via solar reduction experiments. Two generations of models in the Geoengineering Model Intercomparison Project (GeoMIP) have now simulated offsetting a quadrupling of the $\mathrm{CO}_{2}$ concentration with solar reduction. This simulation is idealized and designed to elicit large responses in the models. Here, we show that energetics, temperature, and hydrological cycle changes in this experiment are statistically indistinguishable between the two ensembles. Of the variables analyzed here, the only major differences involve highly parameterized and uncertain processes, such as cloud forcing or terrestrial net primary productivity. We conclude that despite numerous structural differences and uncertainties in models over the past two generations of models, including an increase in climate sensitivity in the latest generation of models, the models
\end{abstract}

are consistent in their aggregate climate response to global solar dimming.

\section{Introduction}

Solar geoengineering describes a set of technologies designed to (ideally) temporarily, deliberately reduce some of the effects of climate change by changing the radiative balance of the planet, often by reflecting sunlight back to space (NRC, 2015). Numerous methods have been proposed, but the most studied is stratospheric sulfate aerosol injection (Budyko, 1977; Crutzen, 2006). This method involves substantially increasing the stratospheric sulfate aerosol burden, replicating the mechanisms that cause cooling after large volcanic eruptions (Robock, 2000), although one might expect different climate responses from pulse versus sustained injections (Robock et al., 2013). Climate models are currently 
the only tools for understanding the climatic consequences of solar geoengineering. In model simulations of solar geoengineering, insolation reduction is often used as a proxy for actual stratospheric sulfate aerosols, as it captures many of the broad radiative effects of stratospheric aerosol geoengineering as well as some of the important climate effects like surface cooling and hydrological cycle strength reduction (Niemeier et al., 2013; Kalidindi et al., 2015). However, stratospheric sulfate aerosols also absorb longwave radiative flux, which heats the upper troposphere and lower stratosphere. As such, any implementation of stratospheric geoengineering with sulfate aerosols would produce additional effects, such as changing atmospheric circulation in response to stratospheric heating and heating gradients (e.g., Richter et al., 2017; Tilmes et al., 2018; Simpson et al., 2019) and stratospheric ozone changes (e.g., Pitari et al., 2014), as well as changes in ultraviolet radiative flux and enhanced diffuse radiation at the surface (Madronich et al., 2018). However, here we consider the major, large-scale effect of reflecting sunlight to cool Earth.

Simulations of solar geoengineering with solar reduction have long shown that solar geoengineering would cool the planet, offsetting global warming (e.g., Govindasamy and Caldeira, 2000; NRC, 2015; Irvine et al., 2016), although there would still be residual regional effects (e.g., Kravitz et al., 2014). Idealized simulations of solar reduction have also been simulated in a multi-model context under the Geoengineering Model Intercomparison Project (GeoMIP; Kravitz et al., 2011), to understand the robust model responses to various standardized solar geoengineering simulation designs. Multi-model conclusions from these studies indicate that solar geoengineering would be effective at partially offsetting greenhouse-gas-induced temperature changes (Kravitz et al., 2013a), as well as changes in the hydrological cycle (Tilmes et al., 2013), the cryosphere (Moore et al., 2014), extreme events (Curry et al., 2014; Aswathy et al., 2015), vegetation (Glienke et al., 2015), circulation (Guo et al., 2018; Gertler et al., 2020), agricultural yield potential (Xia et al., 2014), and numerous other areas. However, the offset is not exact (Moreno-Cruz et al., 2012), particularly on a regional basis or when considering multiple simultaneous metrics of climate change (Kravitz et al., 2014; Irvine et al., 2019), leading to concerns about winners and losers from geoengineering (Ricke et al., 2010). To some extent, the effects of solar geoengineering may be tailored or designed (MacMartin et al., 2013; Kravitz et al., 2016, 2017, 2019), but solar geoengineering will still not be able to completely offset climate change from greenhouse gases.

The previous phase of GeoMIP was associated with the CMIP5 (Taylor et al., 2012), an international collaboration of climate models to attempt to understand robust model responses to various forcings. GeoMIP has now entered a new phase, concurrent with CMIP6 (CMIP6; Eyring et al., 2016), and with it are new solar geoengineering simulations with new and updated versions of the participating Earth system models (Kravitz et al., 2015). As such, this is an opportunity to revisit some central questions in solar geoengineering. Many of the CMIP5 results regarding solar geoengineering showed substantial agreement across the participating GeoMIP models. In this newest iteration of GeoMIP, do the same science conclusions still hold, and do the models still generally agree on the resulting climate effects? Here, we address these questions by evaluating and comparing general climate model response to GeoMIP experiment G1 (described in the next section) from both CMIP5 and CMIP6.

\section{Simulations and participating models}

In this study, we evaluate GeoMIP experiment G1, in which, starting from a pre-industrial control (piControl) baseline, the atmospheric $\mathrm{CO}_{2}$ concentration is instantaneously quadrupled (the standard CMIP experiment abrupt4xCO2), and insolation is simultaneously reduced such that net topof-atmosphere (TOA) radiative flux is within $\pm 0.1 \mathrm{~W} \mathrm{~m}^{-2}$ of the baseline value in the first decade of simulation (Kravitz et al., 2011, 2015). This experiment was part of the original suite of GeoMIP experiments and was repeated and extended in the newest suite in an effort to understand the role of model structural uncertainty in broad conclusions about solar geoengineering. Participating models are listed in Table 1 . We include 13 models from CMIP5 and 7 models from CMIP6. Experiment G1 is an idealized experiment aimed at understanding physical climate response and not as a proposed real-world geoengineering implementation. Although G1 should not be used directly for impacts analysis, improved understanding of climate model response to G1 will increase confidence when evaluating more policy-relevant scenarios.

The original G1 experiment was 50 years in length, whereas the CMIP6 version is 100 years in length to allow for better analyses of rare events and to capture very slow responses. Comparison between the two ensembles necessitates only using the first 50 years, but we need to verify that this can be done without losing important longer-term evolution in features. Figures 1 and 2 look at G1 behavior over the entire 100-year period of the CMIP6 simulations to determine whether there is any drift or steady-state error that would not be revealed by only analyzing the first 50 years. (Also see Table 2 for quantitative information.) Over years 11-100 of simulation, CNRM-ESM2.1 and IPSL-CM6A-LR show negative trends in temperature greater than $0.1 \mathrm{~K} \mathrm{decade}^{-1}$ in magnitude, and CESM2(WACCM) and UKESM1.0-LL shows positive trends of similar magnitudes. This is despite no model showing a trend in net TOA radiative flux greater in magnitude than $0.02 \mathrm{~W} \mathrm{~m}^{-2}$ decade $^{-1}$. Beyond an initial transient period, CESM2(WACCM), CNRM-ESM2.1, and IPSLCM6A-LR show approximately $0.06 \%$ decade $^{-1}$ trends in precipitation and evaporation of the same sign as the temper- 
Table 1. All participating models in both the CMIP5 and CMIP6 eras of GeoMIP, including references. For G1 solar reduction, the percentage is calculated as the percent change in incident solar irradiance at the TOA between G1 and its respective piControl run. Numbers in the first column correspond to the model numbers in Fig. 11.

\begin{tabular}{|c|c|c|c|c|c|c|}
\hline No. & Model & Generation & Reference & $\begin{array}{r}\text { G1 solar } \\
\text { reduction }(\%)\end{array}$ & $\begin{array}{l}\text { Data not } \\
\text { available }\end{array}$ & $\begin{array}{l}\text { Data citations } \\
\text { (CMIP6 only) }\end{array}$ \\
\hline 1 & BNU-ESM & CMIP5 & Ji et al. (2014) & 3.80 & Cloud forcing & \\
\hline 2 & CanESM2 & CMIP5 & Arora et al. (2011) & 4.00 & & \\
\hline 3 & CCSM4 & CMIP5 & Gent et al. (2011) & 4.25 & NPP & \\
\hline 4 & CESM-CAM5.1-FV & CMIP5 & $\begin{array}{l}\text { Neale et al. (2010), } \\
\text { Hurrell et al. (2013) }\end{array}$ & 4.70 & & \\
\hline 5 & CSIRO-Mk3L-1.2 & CMIP5 & Phipps et al. $(2011,2012)$ & 3.20 & $\begin{array}{l}\text { Cloud forcing, } \\
\text { NPP }\end{array}$ & \\
\hline 6 & EC-EARTH & CMIP5 & Hazeleger et al. (2011) & 4.12 & $\begin{array}{l}\text { Cloud forcing, } \\
\text { NPP }\end{array}$ & \\
\hline 7 & GISS-E2-R & CMIP5 & Schmidt et al. (2014) & 4.47 & & \\
\hline 8 & HadCM3 & CMIP5 & Gordon et al. (2000) & 4.16 & $\begin{array}{l}\text { Cloud forcing, } \\
\text { NPP }\end{array}$ & \\
\hline 9 & HadGEM2-ES & CMIP5 & Collins et al. (2011) & 3.88 & & \\
\hline 10 & IPSL-CM5A-LR & CMIP5 & $\begin{array}{l}\text { Dufresne et al. (2013), } \\
\text { Hourdin et al. (2012) }\end{array}$ & 3.50 & NPP & \\
\hline 11 & MIROC-ESM & CMIP5 & Watanabe et al. $(2008,2011)$ & 5.00 & & \\
\hline 12 & MPI-ESM-LR & CMIP5 & $\begin{array}{l}\text { Giorgetta et al. (2013), } \\
\text { Stevens et al. (2013) }\end{array}$ & 4.68 & & \\
\hline 13 & NorESM1-M & CMIP5 & $\begin{array}{l}\text { Alterskjær et al. (2012), } \\
\text { Kirkevåg et al. (2013) }\end{array}$ & 4.03 & & \\
\hline 14 & CanESM5 & CMIP6 & Swart et al. (2019c) & 3.72 & & $\begin{array}{l}\text { Swart et al. (2019a, b), } \\
\text { Cole et al. (2019) }\end{array}$ \\
\hline 15 & CESM2-WACCM & CMIP6 & Gettelman et al. (2019) & 4.91 & & Danabasoglu (2019a, b, c) \\
\hline 16 & CNRM-ESM2.1 & CMIP6 & Séférian et al. (2019) & 3.72 & & Séférian (2018a, b, c) \\
\hline 17 & GISS-E2.1-G & CMIP6 & Kelley et al. (2020) & 4.13 & & $\begin{array}{l}\text { NASA Goddard Institute for } \\
\text { Space Studies (NASA/GISS) } \\
(2019,2018)\end{array}$ \\
\hline 18 & IPSL-CM6A-LR & CMIP6 & $\begin{array}{l}\text { Boucher et al. (2020), } \\
\text { Lurton et al. (2020) }\end{array}$ & 4.10 & & Boucher et al. (2018a, b, c) \\
\hline 19 & MPI-ESM1.2-LR & CMIP6 & Mauritsen et al. (2019) & 4.57 & & Wieners et al. (2019a, b) \\
\hline 20 & UKESM1.0-LL & CMIP6 & Sellar et al. (2019) & 3.80 & & $\begin{array}{l}\text { Tang et al. }(2019 a, b) \text {, } \\
\text { Jones (2019) }\end{array}$ \\
\hline
\end{tabular}

ature trends. Nevertheless, the differences in temperature and hydrological cycle change due to experiment G1 are orders of magnitude greater than the calculated values in Table 2. As such, we conclude that our choice to focus on the first 50 years of simulation does not appreciably affect our results.

Figure 2 shows that many of the models have lowfrequency variability that appears in the different regions plotted here. For the region north of $30^{\circ} \mathrm{N}$, IPSL-CM6A-LR has a steadily increasing temperature value, possibly related to a slight trend in sea ice coverage (Boucher et al., 2020).

IPSL-CM6A-LR is also known to have a bicentennial oscillation, which could affect G1-piControl differences, depending on the baseline period used for subtraction. To verify that this oscillation is not impacting our results, we divided that model's 1200-year piControl run into 50-year chunks and computed the surface air temperature average for each of those chunks. The largest temperature found was 
Table 2. Decadal trends in the global mean temperature, net TOA radiative flux, precipitation, and evaporation values shown in Fig. 1 for each model. Trends are calculated across the years 11-100 to eliminate any effects due to initial transient adjustment to the abrupt forcing.

\begin{tabular}{lrrrr}
\hline Model & $\begin{array}{r}\text { Temperature } \\
\left(\mathrm{K} \mathrm{decade}^{-1}\right)\end{array}$ & $\begin{array}{r}\text { Rad. flux } \\
\left(\mathrm{W} \mathrm{m}^{-2} \mathrm{decade}^{-1}\right)\end{array}$ & $\begin{array}{r}\text { Precipitation } \\
\left(\% \mathrm{decade}^{-1}\right)\end{array}$ & $\begin{array}{r}\text { Evaporation } \\
\left(\% \mathrm{decade}^{-1}\right)\end{array}$ \\
\hline CanESM5 & 0.010 & -0.005 & 0.011 & 0.011 \\
CESM2(WACCM) & 0.023 & -0.009 & 0.067 & 0.067 \\
CNRM-ESM2.1 & -0.033 & 0.016 & -0.058 & -0.058 \\
GISS-E2.1-G & -0.005 & 0.018 & -0.006 & -0.006 \\
IPSL-CM6A-LR & -0.027 & 0.015 & -0.062 & -0.063 \\
MPI-ESM1.2-LR & -0.003 & -0.000 & -0.015 & -0.016 \\
UKESM1.0-LL & 0.018 & 0.008 & 0.018 & 0.018 \\
Ensemble mean & -0.002 & 0.006 & -0.006 & -0.007 \\
\hline
\end{tabular}
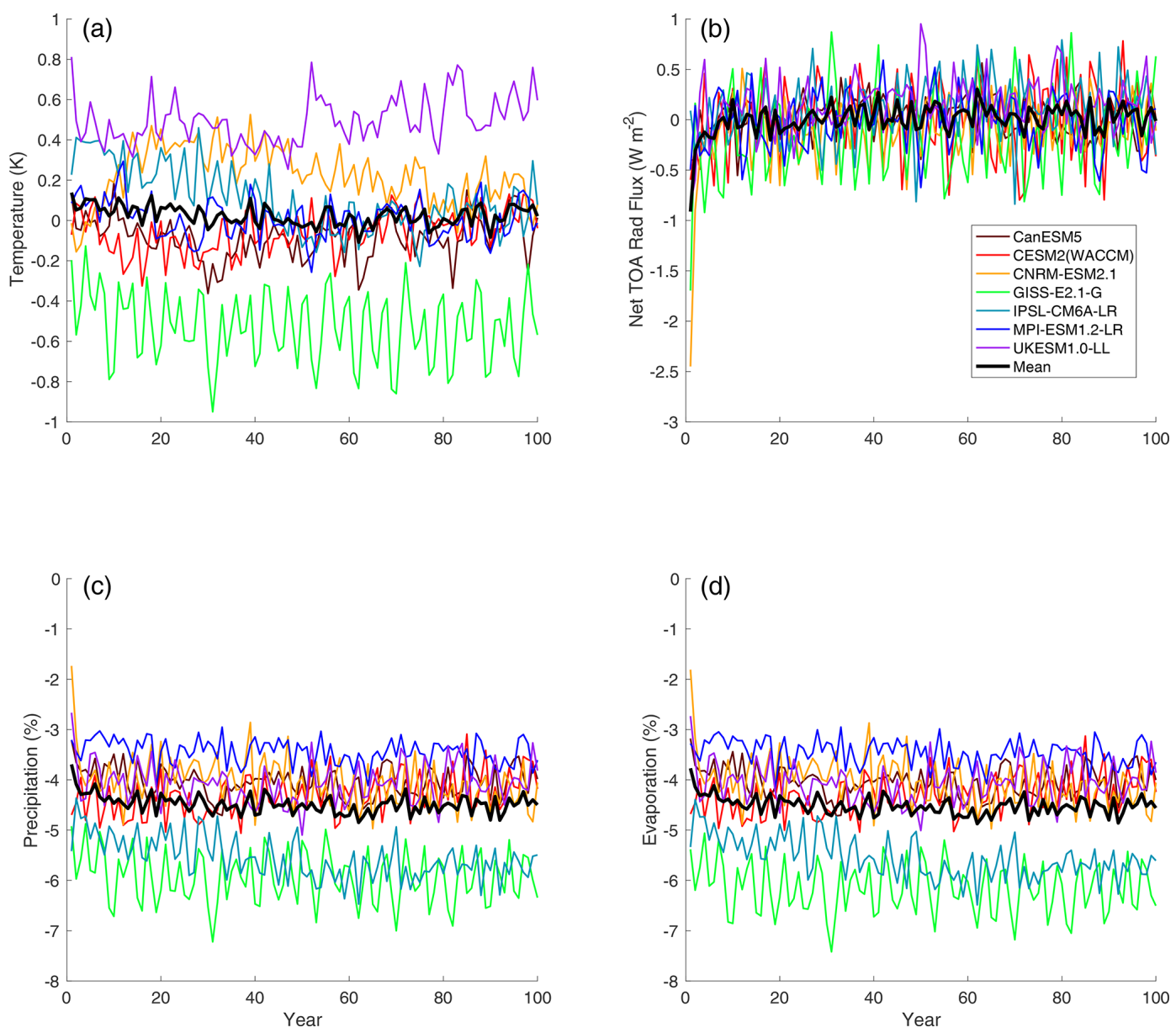

Figure 1. Temperature $(\mathbf{a} ; \mathrm{K})$, net top-of-atmosphere radiative flux $\left(\mathbf{b} ; \mathrm{W} \mathrm{m}^{-2}\right)$, precipitation (c; \%), and evaporation $(\mathbf{d} ; \%)$ change in G1 $1_{\text {CMIP6 }}$ compared to piControl over 100 years of simulation. Thin colored lines are individual models, and thick black lines are ensemble means.

$286.0339 \mathrm{~K}$, and the smallest was $285.6384 \mathrm{~K}$. The average over the entire ensemble was $285.8604 \mathrm{~K}$. As such, using the mean of the entire ensemble versus matching the appropriate period in the bicentennial oscillation would have an impact on G1-piControl temperature by at most $0.22 \mathrm{~K}$. Only averaging the first 100 years of the piControl run (which may be the best match to the period covered by G1) yields a temperature of $285.9084 \mathrm{~K}$, which is $0.048 \mathrm{~K}$ different from the mean of the entire piControl run. As such, we conclude that this bicentennial oscillation is unlikely to have substantially influenced our findings. 

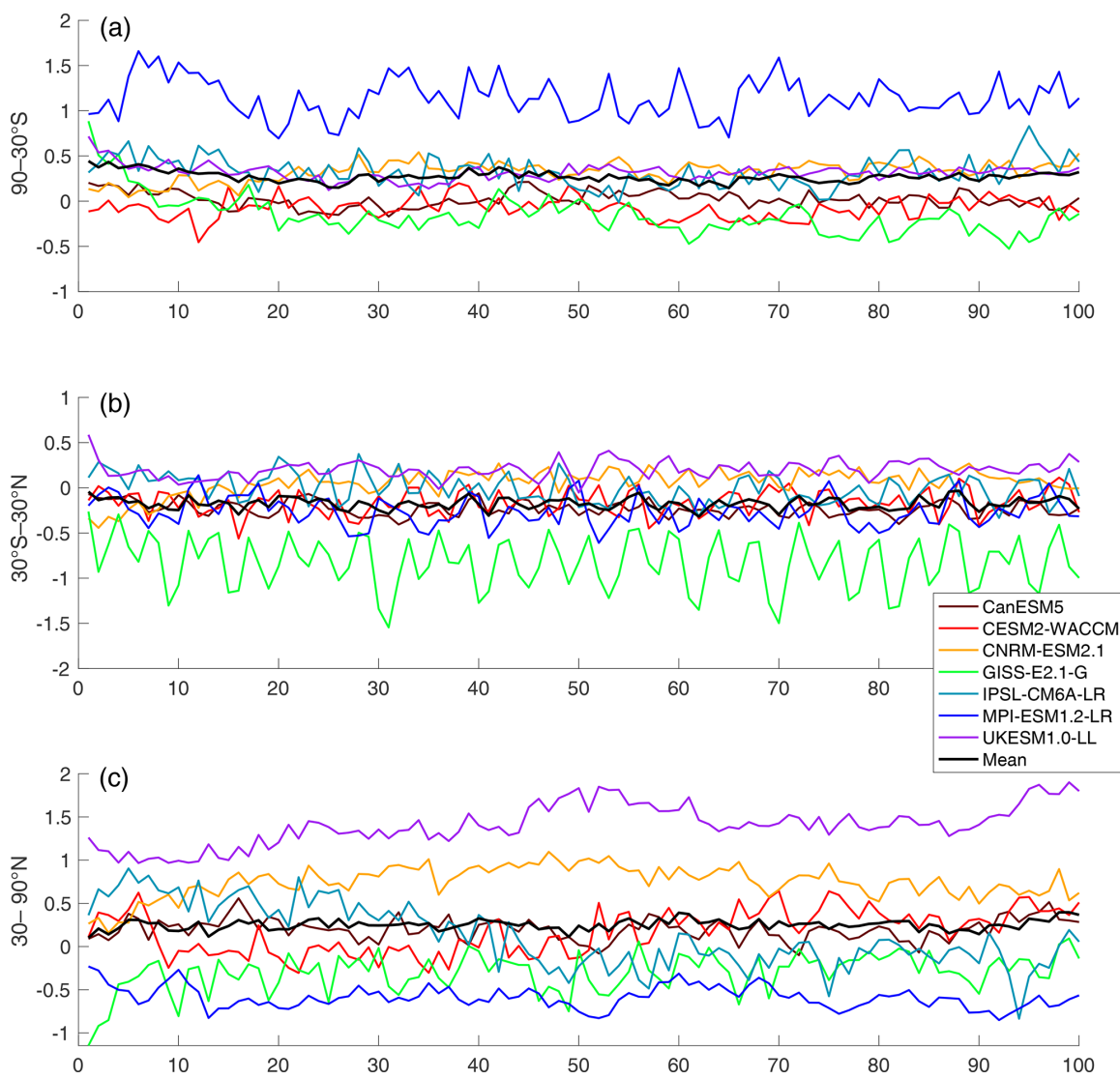

Figure 2. Annual mean surface temperature (K) in each model averaged over $90-30^{\circ} \mathrm{S}(\mathbf{a}), 30^{\circ} \mathrm{S}-30^{\circ} \mathrm{N}(\mathbf{b})$, and $30-90^{\circ} \mathrm{N}(\mathbf{c})$. The ensemble mean is plotted as thick black lines.

Per the results in Fig. 1, IPSL-CM6A-LR and GISS-E2.1$\mathrm{G}$ appear to have a different responsiveness of the hydrological cycle to the combined $\mathrm{CO}_{2}$-solar forcing than the other models. We are reluctant to attribute this feature to any potential shortcomings or lack of fidelity to observations because there are no observations of this type of experiment. Although these models are outliers, there is no evidential basis on which to assume they are more or less valid than the other models for this study.

Because the main focus of this paper is a comparison between the CMIP5 and CMIP6 generations of model results, we have opted for the following to aid comparisons:

- Since we are not evaluating any features that require 100 years of statistics, and the results do not show any appreciable time evolution of behavior after the first couple of years (see discussion above), we only evaluate the first 50 years of all simulations. All maps show changes over years 11-50, removing the initial transient period.

- We do not compare previous versions of individual models with current ones, instead only examining ensembles. Even though models may share similar development histories (e.g., atmosphere and ocean dynamical cores, convective parameterizations, radiative transfer modules, terrestrial biosphere and cryosphere; Knutti et al., 2013; Zelinka et al., 2020), there have been numerous developments in models in these areas (and others) between CMIP5 and CMIP6 such that in most cases a direct comparison would not be meaningful.

- We focus extensively on the G1 results and, with few exceptions, do not focus on the corresponding abrupt $4 \mathrm{xCO} 2$ simulations. It has been well documented that the CMIP6 models tend to have higher climate sensitivities than the CMIP5 models (Flynn and Mauritsen, 2020; Meehl et al., 2020; Zelinka et al., 2020), so we do not wish to make conclusions that might be based on a form of selection bias.

- All lack of stippling on map plots, as in previous GeoMIP studies (e.g., Kravitz et al., 2013a), indicates agreement on the sign of the response in at least $75 \%$ of models. Because $\mathrm{G}_{\mathrm{CMIP} 5}$ has more participating models than $\mathrm{G}_{\mathrm{CMIP} 6}$, this threshold provides some consistency across analyses of the ensembles. When plotting differences between the ensembles $\left(\mathrm{G}^{\mathrm{CM}} \mathrm{CM}^{-}\right.$

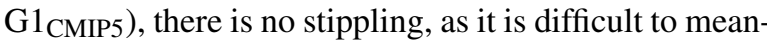


ingfully represent such differences between ranges. Aggregate differences between the two ensembles, as calculated using Welch's $t$ test or differences in stippled area, are discussed in Table 3.

For CMIP6, we analyzed one ensemble member for all experiments except for CanESM5 (G1), CNRM-ESM2.1 (abrupt4xCO2 and G1), and UKESM1.0-LL (G1).

\section{Results}

\subsection{Energetics}

Ensemble mean radiative and turbulent flux quantities are plotted in Fig. 3, and the ensemble ranges are plotted in Fig. 4. An immediate observation is that, in both ensembles, the models were successful at limiting net TOA radiative flux change to within approximately $\pm 0.1 \mathrm{~W} \mathrm{~m}^{-2}$ of the models' respective pre-industrial values. Accomplishing this required an average solar reduction of $4.14 \%$ (models range within $3.20 \%-5.00 \%)$ in CMIP5 and $4.14 \%(3.72 \%-4.91 \%)$ in CMIP6. As such, despite numerous structural changes between the two generations of models, there is no appreciable change in solar efficacy (Hansen et al., 2005).

None of the radiative flux quantities indicate large transients over 50 years of simulation of G1, other than the initial flux change within the first year or so of simulation. This is consistent with the "perpetual fast response" found by Kravitz et al. (2013b), in which because global mean temperature does not change appreciably over the course of the G1 simulation, climate feedbacks are not excited, and the internal state of the system (as measured by, for example, fluxes and hydrological cycle changes) similarly does not change. Ensemble mean fluxes show few differences $\left(<1 \mathrm{~W} \mathrm{~m}^{-2}\right.$ in magnitude) with the exception of shortwave cloud forcing, defined as all-sky minus clear-sky shortwave flux at the surface. On average, the CMIP6 ensemble has $3-4 \mathrm{~W} \mathrm{~m}^{-2}$ less shortwave cloud forcing than CMIP5. Neglecting some outliers, for each flux except shortwave (and hence total) cloud forcing, the median model in one ensemble is within the interquartile range of the other ensemble. This indicates that there are no major differences between the ensembles in how the models handle energy balance and energetics, with the exception of clouds, which is consistent with findings about CMIP6 (Zelinka et al., 2020). Moreover, it appears that most of the major differences in shortwave cloud forcing are due to outliers in each ensemble, which are positive for CMIP5 and negative for CMIP6. To further explore these potential differences, Fig. 5 provides maps of the ensemble means for cloud forcing. In G1, the CMIP5 ensemble showed more positive shortwave cloud forcing and more negative longwave cloud forcing (i.e., more cancellation) than the CMIP6 ensemble. Overall, the CMIP6 ensemble has greatly reduced (in some places by over $10 \mathrm{~W} \mathrm{~m}^{-2}$ ) shortwave cloud forcing as compared to CMIP5 under the G1 experiment. This is a
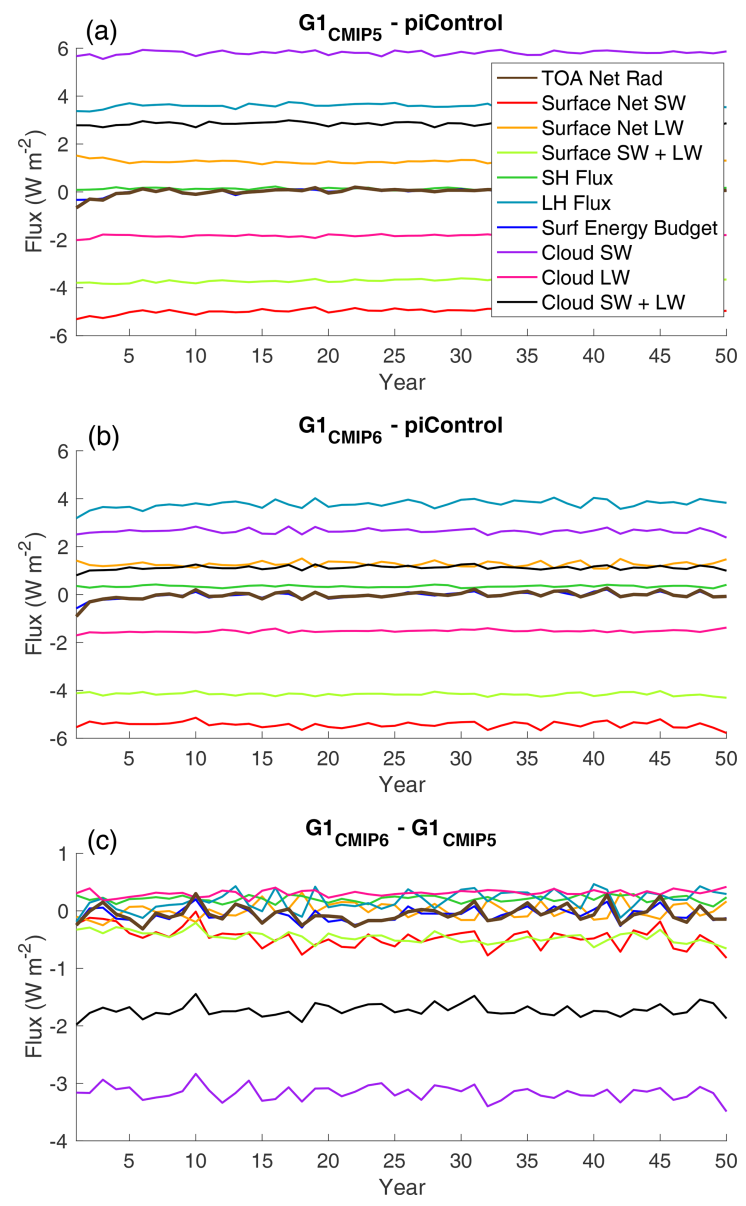

Figure 3. Ensemble mean energetics $\left(\mathrm{W} \mathrm{m}^{-2}\right)$ for various flux quantities in G1 $_{\text {CMIP5 }}$ (a), G1 $1_{\text {CMIP6 }}$ (b), and their difference (c). All fluxes are positive downward, which is counterintuitive for sensible heat $(\mathrm{SH})$ and latent heat (LH). Surf energy budget indicates the sum of surface shortwave (SW), surface longwave (LW), $\mathrm{SH}$, and LH. Cloud forcing is calculated as all-sky minus clear-sky radiative flux.

widespread result, but the most prominent features are in the tropics, especially over the Amazon, Africa, and the Maritime Continent. These regions encompass tropical forests, indicating a potential for vegetation feedbacks on the temperature reductions. However, the reasons behind these forcing changes are difficult to diagnose, as they could be due to changes in cloud thickness, cloud cover, or cloud level between CMIP5 and CMIP6 models (e.g., Vignesh et al., 2020), differences in how solar geoengineering affects clouds (Russotto and Ackerman, 2018), or artifacts of the analyses (e.g., cloud masking; Andrews et al., 2009; Kravitz et al., 2013b). Moreover, based on the results in Fig. 4, it is likely that many of these features are exaggerated by outlier models (also see Vignesh et al., 2020). As such, we reserve such detailed investigations for future work. 
Table 3. Ensemble differences between the CMIP5 and CMIP6 ensembles for each variable evaluated in this study (left column). Column 2 indicates the difference between the ensembles in how much of the Earth's surface is not stippled (more than $75 \%$ of models agree on the sign of the response; negative values indicate that CMIP6 has less unstippled area than CMIP5). Column 3 indicates the percent of the Earth's surface for which the CMIP5 ensemble is statistically different from the CMIP6 ensemble, based on 95th percentile confidence intervals from Welch's $t$ test.

\begin{tabular}{lrrl}
\hline Variable & Stippling $(\%)$ & Welch's $t$ test $(\%)$ & Notes \\
\hline Surface air temperature & -25.77 & 0.87 & \\
Precipitation & -3.56 & 11.17 & \\
Evaporation & -2.33 & 6.47 & \\
$P-E$ & -15.23 & 1.13 & \\
SW cloud forcing & -8.02 & 9.65 & \\
LW cloud forcing & 11.99 & 6.57 & \\
Net primary productivity & -1.42 & 1.15 & Land surface only \\
\hline
\end{tabular}

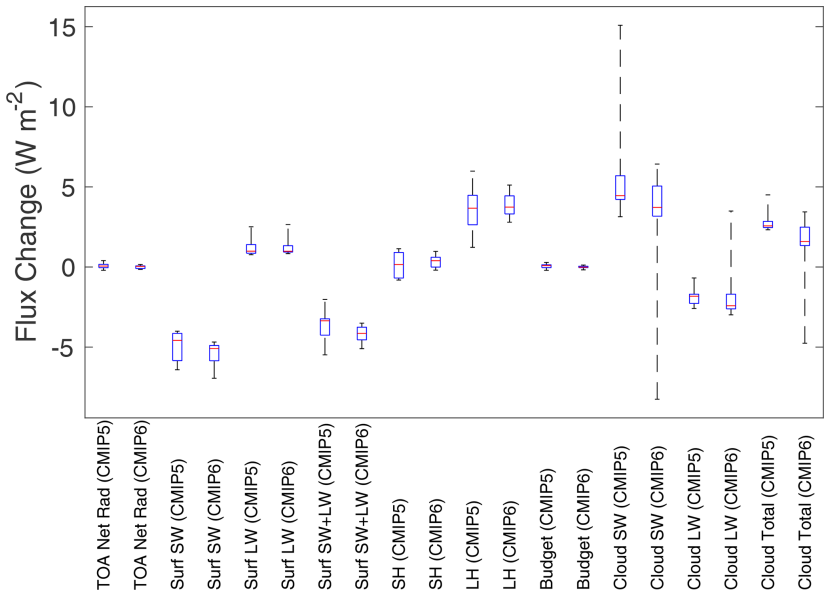

Figure 4. Ensemble median (red lines), interquartile (blue boxes), and ranges (black whiskers) for the same global mean energetic quantities as in Fig. 3 (G1 minus piControl) for both the CMIP5 and CMIP6 ensembles.

\subsection{Temperature}

These small flux changes also led to few G1 temperature changes between the two ensembles. Figure 6 shows global-, land-, and ocean-averaged temperatures for the CMIP5 and CMIP6 ensembles. In general, the abrupt $4 \mathrm{xCO} 2$ simulation in CMIP6 has higher temperatures than in CMIP5, consistent with the noted increase in climate sensitivity (Vial et al., 2013; Flynn and Mauritsen, 2020; Meehl et al., 2020; Zelinka et al., 2020). In both ensembles, G1 is effective at offsetting global mean temperature change, in some cases with a slight positive residual temperature change over land. Figure 7 shows three aggregate temperature metrics: global mean temperature $\left(T_{0}\right)$, the interhemispheric temperature gradient $\left(T_{1}\right)$, and the Equator-to-pole temperature gradient $\left(T_{2}\right)$ (Ban-Weiss and Caldeira, 2010; Kravitz et al., 2016):
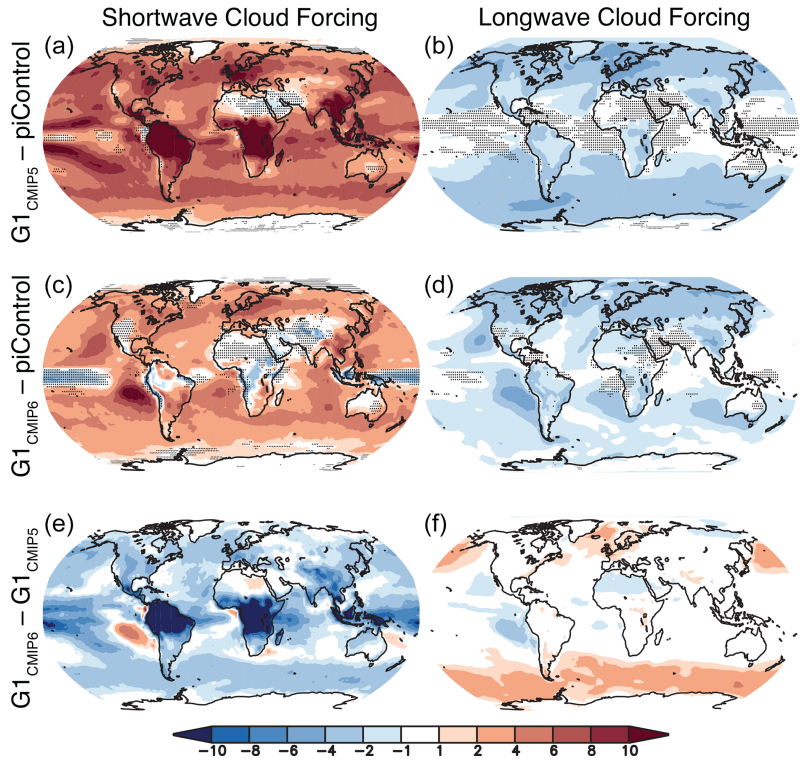

Figure 5. Surface shortwave (a, c, e) and longwave (b, d, f) cloud forcing $\left(\mathrm{W} \mathrm{m}^{-2}\right)$ change from pre-industrial values for the CMIP5 (a, b) and CMIP6 (c, d) ensembles, as well as the ensemble differences $(\mathbf{e}, \mathbf{f})$. Cloud forcing is measured as all-sky minus clearsky radiative flux. All shaded values are ensemble means. Lack of stippling indicates agreement on the sign of the values across at least $75 \%$ of the models.

$$
\begin{aligned}
& T_{0}=\frac{1}{A} \int_{-\pi / 2}^{\pi / 2} T(\psi) \mathrm{d} A \\
& T_{1}=\frac{1}{A} \int_{-\pi / 2}^{\pi / 2} T(\psi) \sin \psi \mathrm{d} A \\
& T_{2}=\frac{1}{A} \int_{-\pi / 2}^{\pi / 2} T(\psi) \frac{1}{2}\left(3 \sin ^{2} \psi-1\right) \mathrm{d} A,
\end{aligned}
$$



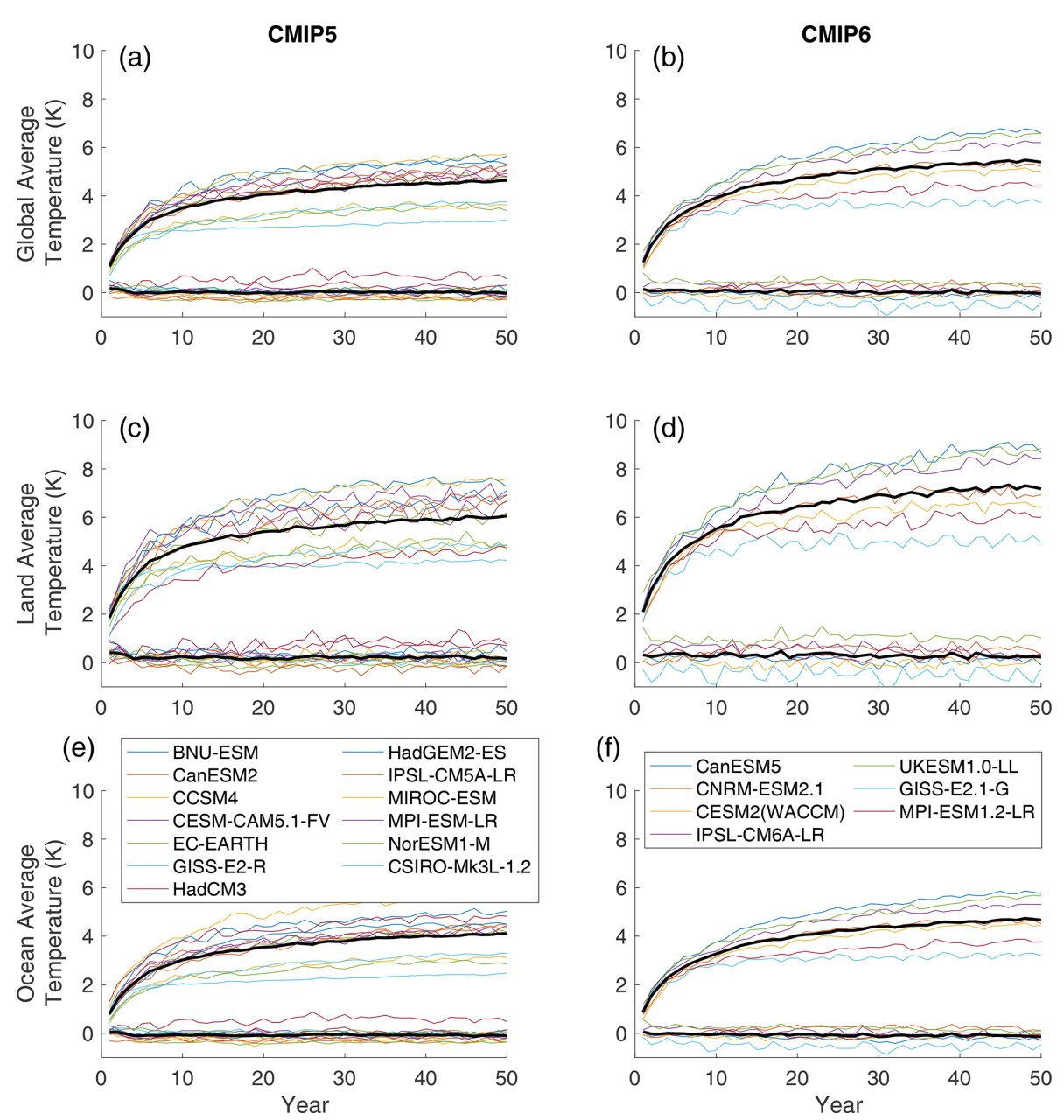

Figure 6. Global mean (a, b), land mean (c, d), and ocean mean (e, f) temperature change (K) for the CMIP5 (a, c, e) and CMIP6 (b, d, f). Thin colored lines are individual models, and thick black lines are model means. In all panels, the upper cluster of lines is the abrupt $4 \mathrm{xCO} 2$ simulation, and the lower cluster of lines (approximately zero temperature change for the entire simulation) is experiment G1.

where $A$ is area. As for the fluxes, the median model in one ensemble is within the interquartile range of the other ensemble. This indicates that no ensemble is on average warmer or cooler than another, has a substantially warmer Northern or Southern Hemisphere than the other, nor warmer tropics or poles than the other. We can conclude that spatial patterns of temperature change from $\mathrm{G} 1$ are robust across a wide range of structural uncertainty, including an increase in climate sensitivity between the two generations of CMIP.

The spatial structure of temperature change (Fig. 8) does have small differences between the two ensembles. G1 in CMIP6 has multiple locations that are warmer than G1 in CMIP5, despite both ensembles achieving net energy balance at TOA and the surface (Fig. 3). The majority of the differences are over land and in the tropics, where CMIP6 is slightly warmer than CMIP5 (up to $1{ }^{\circ} \mathrm{C}$ in some places). Nevertheless, both ensembles show the well-noted feature that offsetting a $\mathrm{CO}_{2}$ increase with globally uniform solar reduction overcools the tropics and undercools the poles (Govindasamy and Caldeira, 2000; Kravitz et al., 2013a). CMIP6 shows slightly less high-latitude warming than CMIP5, but temperature differences between the two ensembles are largely negligible. However, the warmer temperatures in CMIP6 near Greenland have important implications for ice sheet melt and consequent sea level rise, as well as bottom water formation. We reserve such analyses for future investigations, particularly since the models used here are not capable of simulating the eustatic component of sea level rise. In any case, these ensemble mean differences between CMIP5 and CMIP6 cannot be deemed statistically significant (Table 3 and Fig. 7).

\subsection{Hydrological and other integrative changes}

Figure 9 shows ensemble mean changes in precipitation $(P)$, evaporation $(E)$, and $P-E$ for $\mathrm{G}_{\mathrm{CMIP} 5}$ and $\mathrm{G}_{\mathrm{CMIP6}}$. Qualitatively, patterns are similar between both ensembles. Precipitation is slightly $\left(<0.3 \mathrm{~mm} \mathrm{~d}^{-1}\right.$ in magnitude) differ- 

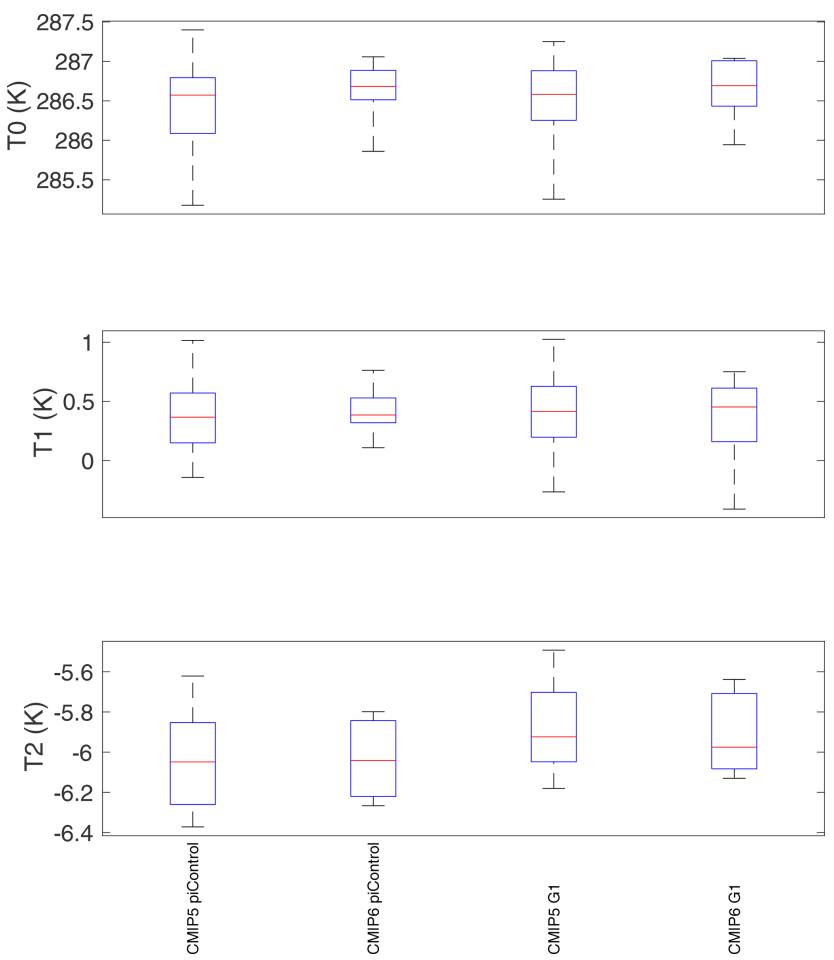

Figure 7. Ensemble ranges for global mean temperature $\left(T_{0}\right)$, the interhemispheric temperature gradient $\left(T_{1}\right)$, and the Equator-to-pole temperature gradient $\left(T_{2}\right)$, as defined in Eq. (1) (Ban-Weiss and Caldeira, 2010; Kravitz et al., 2016). Red lines indicate ensemble medians, blue boxes are the interquartile ranges, and black whiskers indicate total ranges.

ent in the tropics between the two ensembles. The majority of those features can be summarized as a more southward Intertropical Convergence Zone (ITCZ), more precipitation in the South Pacific Convergence Zone, and less precipitation over southeast Asia and the Maritime Continent in G1 $1_{\text {CMIP6 }}$. Evaporation in the two ensembles is nearly identical except for more evaporation in Amazonia and Australia in $\mathrm{G}_{\mathrm{CMIP}}$. As such, the net $P-E$ change between the two ensembles strongly resembles the precipitation changes. Figure 10 shows that, like previous evaluations of ensemble ranges, the median model in one ensemble falls well within the interquartile range of the other ensemble for $P, E$, and $P-E$. As such, we cannot conclude any robust hydrological cycle changes between the two ensembles.

Figure 11 shows average (years 11-50) temperature change (with respect to piControl) plotted against average precipitation change for each model, as in Tilmes et al. (2013). Other than a potentially greater climate sensitivity of some CMIP6 models, there is no distinguishable difference in aggregate behavior between the two ensembles. The same conclusion discovered by Tilmes et al. (2013) holds: solar reduction cannot simultaneously offset $\mathrm{CO}_{2}$-induced changes
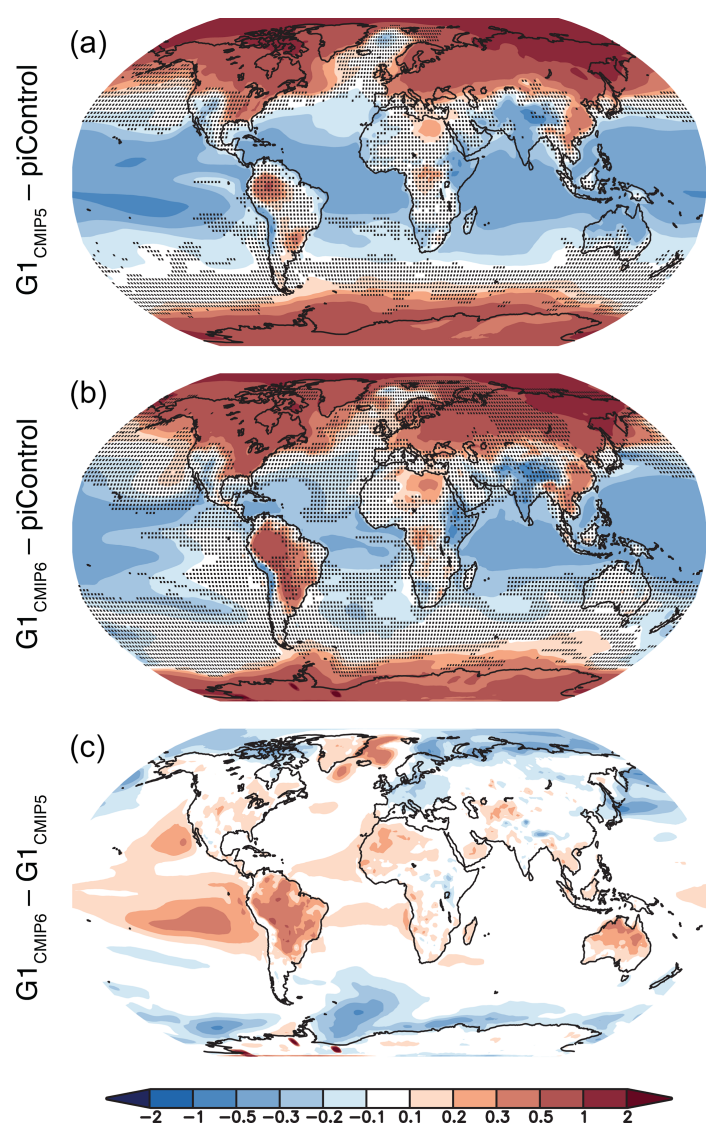

Figure 8. Ensemble average temperature changes (K) for G1 (as compared to the pre-industrial control) for CMIP5 (a) and CMIP6 (b), as well as their difference (G1 $1_{\mathrm{CMIP6}}$ minus $\left.\mathrm{G} 1_{\mathrm{CMIP} 5}, \mathbf{c}\right)$. In panels (a) and (b), stippling indicates regions where fewer than $75 \%$ of the models in their respective ensembles agree on the sign of the response.

in both global mean temperature and global mean precipitation.

As an integrator of $\mathrm{CO}_{2}$, temperature, and precipitation effects over land, Fig. 12 shows changes in terrestrial net primary productivity (NPP). Numerous land regions have lower NPP in CMIP6 than in CMIP5. The ensemble average global NPP change (G1-piControl) is 51.2 (4.1-122.1) $\mathrm{Pg} \mathrm{C} \mathrm{yr}^{-1}$ in CMIP5 and 38.1 (19.5-77.5) $\mathrm{Pg} \mathrm{C} \mathrm{yr}^{-1}$ in CMIP6, representing a $25.6 \%$ difference in means. Jones et al. (2013) used NPP to highlight the importance of understanding the influence of structural land model differences on climate results related to geoengineering. While it is beyond the scope of this study to perform a detailed diagnosis of which uncertainties or processes are responsible for this inter-ensemble difference (and indeed the present setup does not allow for a controlled experiment to rigorously test structural uncertainty), we show that the ensemble spread of total terrestrial NPP is smaller in CMIP6 than in CMIP5. This result is consistent with the recent assessment of carbon cycle feedbacks conducted by Arora et al. (2020), who showed that the 

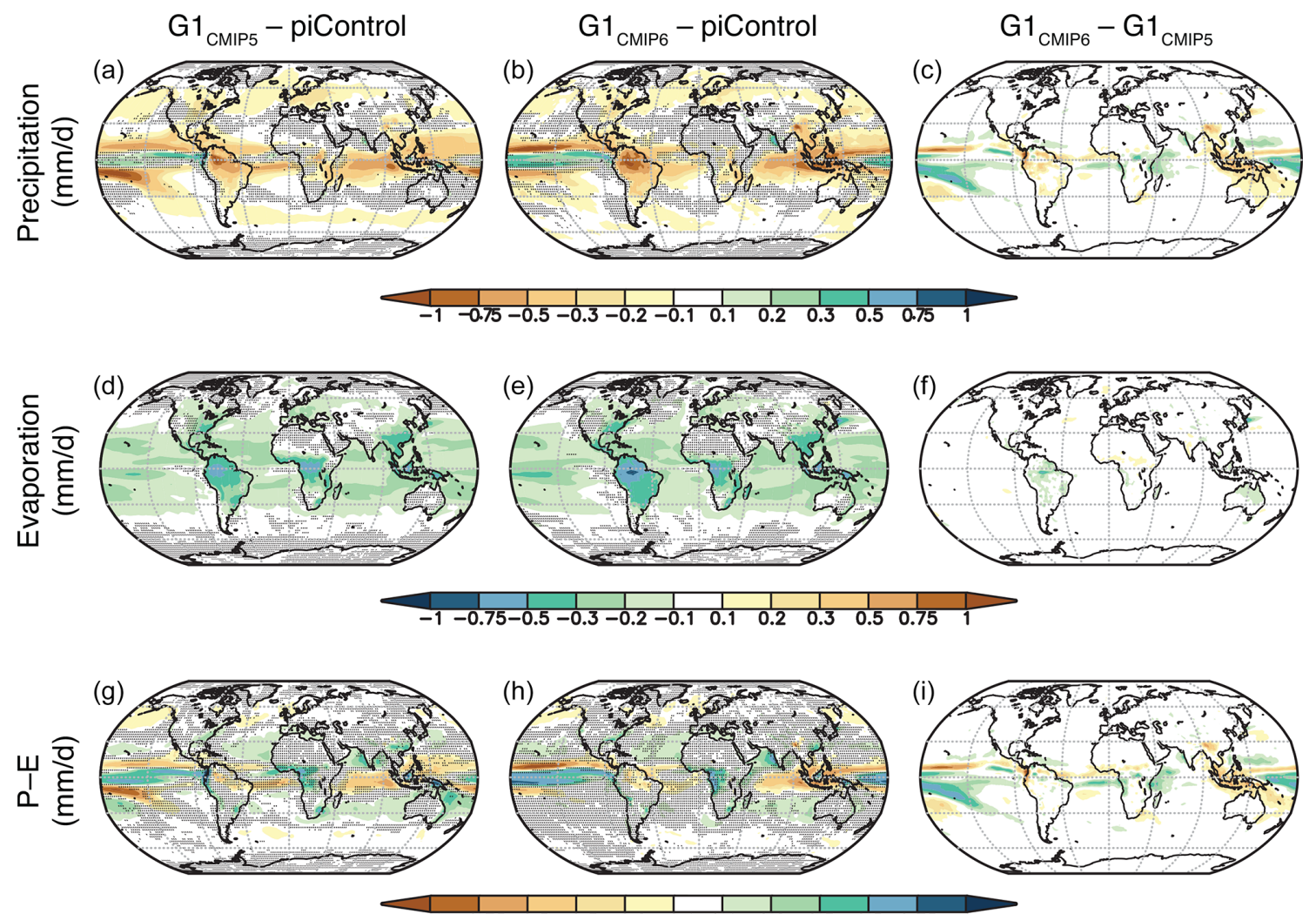

Figure 9. Precipitation $(\mathbf{a}-\mathbf{c})$, evaporation $(\mathbf{d}-\mathbf{f})$, and precipitation minus evaporation $(P-E ; \mathbf{g}-\mathbf{i})$ change from pre-industrial values for the CMIP5 (a, d, g) and CMIP6 (b, e, h) ensembles, as well as the ensemble differences $(\mathbf{c}, \mathbf{f}, \mathbf{i})$. All shaded values are ensemble means. Lack of stippling in the left and middle panels indicates agreement on the sign of the values across at least $75 \%$ of the models.

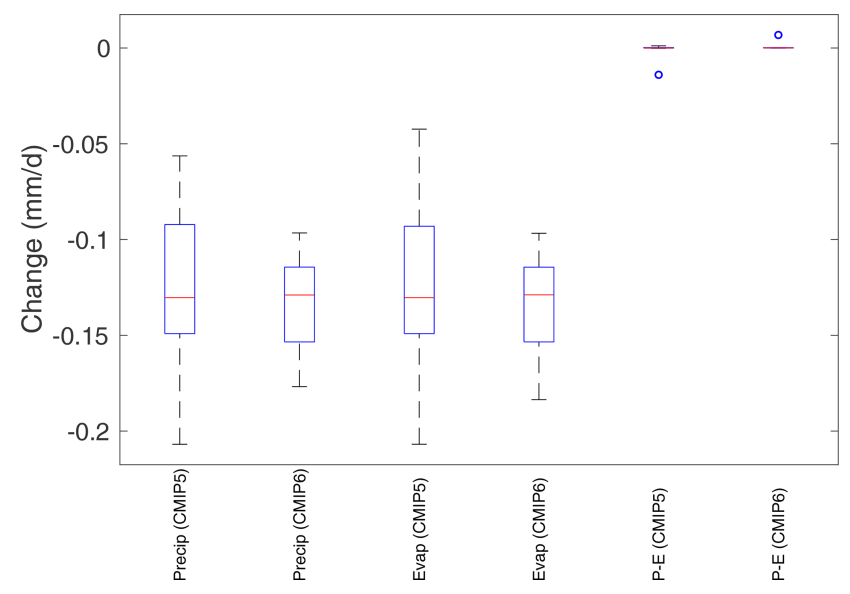

Figure 10. Global mean ensemble median (red lines), interquartile (blue boxes), and ranges (black whiskers or, for $P-E$, one blue circle indicating an extreme outlier) for the hydrological quantities shown in Fig. 9 for both the CMIP5 and CMIP6 ensembles.
CMIP6 ensemble has reduced overall model spread in the land carbon cycle to rising $\mathrm{CO}_{2}$ compared to their CMIP5 predecessors.

\section{Discussion and conclusions}

Based on the results presented here, model response to G1 has not changed substantially between CMIP5 and CMIP6, despite numerous changes to models between the two generations, including an increase in climate sensitivity. The signs of residual climate impacts (for example, in temperature) are in better agreement in CMIP5 than CMIP6 (Table 3 shows a difference in stippled area between the two ensembles), but this could be a function of the smaller ensemble size in CMIP6. Alternatively, the factors affecting the signs of residual climate impacts are not understood well enough for the CMIP6 models to show improvement over CMIP5. Energetics, temperature, and the hydrological cycle are qualitatively and quantitatively similar in both ensemble means and ensemble ranges, although these variables are somewhat related, so we might expect them to all portray a similar picture. Notable differences do exist in shortwave cloud forcing and 


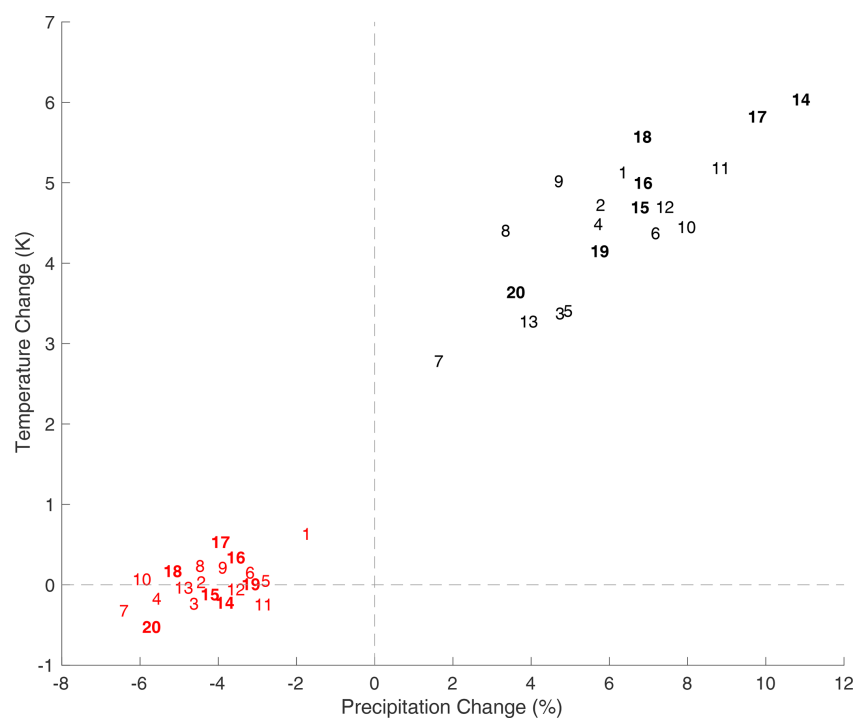

Figure 11. Average (years 11-50) temperature ( $y$ axis; K) and precipitation ( $x$ axis; \%) change for each model in this study. Numbers indicate the model number (listed in Table 1, first column). Black numbers are for abrupt $4 \mathrm{xCO} 2$, and red numbers are for $\mathrm{G} 1$. Bolded numbers are for CMIP6.

NPP, particularly in Amazonia, Africa, and Australia, which are also regions of inter-ensemble difference in precipitation.

From these findings, we can conclude that results obtained over two generations of models have not been overturned by the latest round of simulations. All of the major ensemble differences highlighted above deal with clouds and land surface modeling, both of which are difficult to model and are necessarily highly parameterized. The conclusions that are based on more fundamental knowledge, such as column energetics (in the case of the hydrological cycle), are relatively robust to structural uncertainty, insofar as this study adequately captures representative variations in structural uncertainty. This lends confidence to our conclusions about the broad climate effects from modeling solar geoengineering via solar dimming.

We also conclude that the models used in CMIP5 are not obviously biased or inferior as compared to CMIP6. While improvements have been made in the CMIP6 generation of models, and those models are likely better for representing numerous features of the present-day climate that may be important for studies of geoengineering, there are many aspects of climate that are well represented by earlier models. In some cases, more robust analyses may be enabled by augmenting ensemble sizes with archived output from earlier generations of CMIP models.

Many of the broad features of solar geoengineering with sulfate aerosols can be represented by a reduction in solar constant (e.g., Niemeier et al., 2013; Kalidindi et al., 2015). However, the more subtle changes that derive from complex response to stratospheric aerosol heating (for example, con-
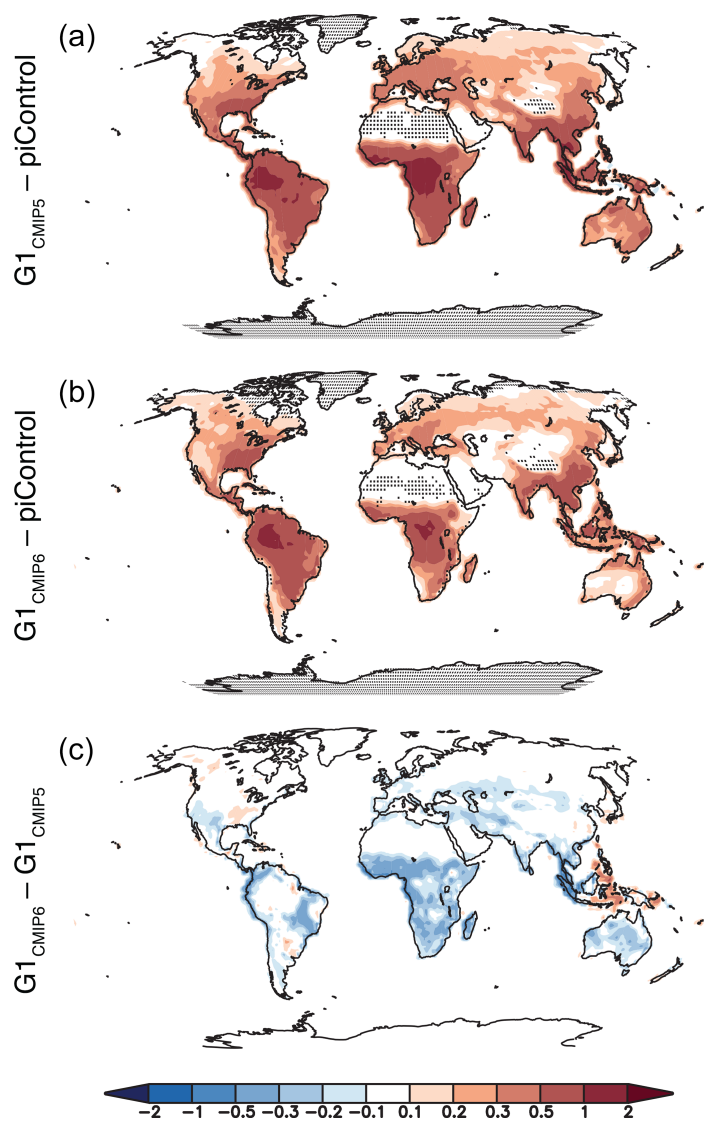

Figure 12. Terrestrial net primary productivity $\left(\mathrm{kg} \mathrm{C} \mathrm{m}^{-2} \mathrm{yr}^{-1}\right)$ for the CMIP5 (a) and CMIP6 (b) ensembles, as well as the ensemble differences (c). All shaded values are ensemble means. Lack of stippling indicates agreement on the sign of the values across at least $75 \%$ of the models.

sequences of stratospheric heating like the positive wintertime North Atlantic Oscillation; Simpson et al., 2019; Jones et al., 2021) require detailed assessments with state-of-theart aerosol microphysical schemes. This is particularly important for understanding regional and seasonal solar geoengineering (Kravitz et al., 2017; Visioni et al., 2019). Such detailed microphysical calculations can only be simulated in a small number of models; in the case of Jones et al. (2021), only two models were available. While simple G1-style experiments enable a robust multi-model ensemble analysis, they cannot capture details that depend on microphysics. We emphasize the importance of a variety of modeling approaches to understand solar geoengineering, particularly the role of model uncertainty in conclusions about solar geoengineering.

There are numerous aspects of physical climate that we did not evaluate, nor did we pursue analyses beyond physical climate, including many other aspects of natural science, social science, the humanities, governance, justice, or ethics (to name a few important areas). Moreover, we emphasize that experiment G1 is an idealized experiment aimed at under- 
standing physical climate response to combinations of large forcings and should not be interpreted as a realistic or policyrelevant scenario of geoengineering. A holistic assessment of the consequences of geoengineering, particularly of more policy-relevant scenarios, would certainly need to take these numerous aspects into account. Nevertheless, based on the results presented here, results for geoengineering across several important metrics appear to be consistent across some important structural uncertainties. This lends confidence to some conclusions drawn from global climate models regarding solar geoengineering.

Data availability. All CMIP5 and CMIP6 output, including the respective GeoMIP simulations, is available via the Earth System Grid Federation (https://esgf-node.llnl.gov/projects/esgf-1lnl/, Lawrence Livermore National Laboratory, 2021) or by contacting the respective modeling groups responsible for the output. For CMIP6 output, see data citations in Table 1.

Author contributions. BK, OB, JNSC, JH, AJ, TL, PN, UN, RS, and ST contributed model output. BK performed the analysis. BK, DGM, and DV wrote the manuscript with all co-authors.

Competing interests. The authors declare that they have no conflict of interest.

Special issue statement. This article is part of the special issue "Resolving uncertainties in solar geoengineering through multi-model and large-ensemble simulations (ACP/ESD inter-journal SI)". It is not associated with a conference.

Acknowledgements. We acknowledge the World Climate Research Programme, which, through its Working Group on Coupled Modelling, coordinated and promoted CMIP. We thank the climate modeling groups for producing and making available their model output, the Earth System Grid Federation (ESGF) for archiving the data and providing access, and the multiple funding agencies who support CMIP6 and ESGF. We also thank all participants of the Geoengineering Model Intercomparison Project and their model development teams.

Financial support. Support for Ben Kravitz was provided in part by the National Science Foundation (NSF) through agreement no. CBET-1931641, the Indiana University Environmental Resilience Institute, and the Prepared for Environmental Change Grand Challenge initiative. The Pacific Northwest National Laboratory is operated for the US Department of Energy by Battelle Memorial Institute under contract no. DE-AC05-76RL01830. Resources supporting this work were provided by the NASA High-End Computing (HEC) Program through the NASA Center for Climate Simulation (NCCS) at Goddard Space Flight Center. Alan Robock is supported by NSF grant nos. AGS-1617844 and AGS-2017113. Jim Haywood and Andy Jones were supported by the Met Office Hadley Centre Climate Programme funded by BEIS and Defra. Ulrike Niemeier is supported by the German DFG-funded Research Unit VollImpact FOR2820 subproject no. TI344/2-1 and MPIESM simulation have been performed on the computer of Deutsches Klimarechenzentrum (DKRZ). Olivier Boucher and Thibaut Lurton were supported by the IPSL Climate Graduate School EUR (ANR grant no. ANR-11-IDEX-0004-17-EURE0006). The CMIP6 project at IPSL used the HPC resources of TGCC under allocations 2016-A0030107732, 2017-R0040110492, and 2018-R0040110492 (project gencmip6) provided by GENCI (Grand Équipement National de Calcul Intensif). Roland Séférian and Pierre Nabat were supported by the H2020 CONSTRAIN under the grant agreement no. 820829 and the Météo-France/DSI supercomputing center.

Review statement. This paper was edited by Xiaohong Liu and reviewed by Ralph Kahn and three anonymous referees.

\section{References}

Alterskjær, K., Kristjánsson, J. E., and Seland, Ø.: Sensitivity to deliberate sea salt seeding of marine clouds - observations and model simulations, Atmos. Chem. Phys., 12, 2795-2807, https://doi.org/10.5194/acp-12-2795-2012, 2012.

Andrews, T., Forster, P. M., and Gregory, J. M.: A surface energy perspective on climate change, J. Climate, 22, 2557-2570, https://doi.org/10.1175/2008JCLI2759.1, 2009.

Arora, V. K., Scinocca, J. F., Boer, G. J., Christian, J. R., Denman, K. L., Flato, G. M., Kharin, V. V., Lee, W. G., and Merryfield, W. J.: Carbon emission limits required to satisfy future representative concentration pathways of greenhouse gases, Geophys. Res. Lett., 38, L05805, https://doi.org/10.1029/2010GL046270, 2011.

Arora, V. K., Katavouta, A., Williams, R. G., Jones, C. D., Brovkin, V., Friedlingstein, P., Schwinger, J., Bopp, L., Boucher, O., Cadule, P., Chamberlain, M. A., Christian, J. R., Delire, C., Fisher, R. A., Hajima, T., Ilyina, T., Joetzjer, E., Kawamiya, M., Koven, C. D., Krasting, J. P., Law, R. M., Lawrence, D. M., Lenton, A., Lindsay, K., Pongratz, J., Raddatz, T., Séférian, R., Tachiiri, K., Tjiputra, J. F., Wiltshire, A., Wu, T., and Ziehn, T.: Carbonconcentration and carbon-climate feedbacks in CMIP6 models and their comparison to CMIP5 models, Biogeosciences, 17, 4173-4222, https://doi.org/10.5194/bg-17-4173-2020, 2020.

Aswathy, V. N., Boucher, O., Quaas, M., Niemeier, U., Muri, H., Mülmenstädt, J., and Quaas, J.: Climate extremes in multi-model simulations of stratospheric aerosol and marine cloud brightening climate engineering, Atmos. Chem. Phys., 15, 9593-9610, https://doi.org/10.5194/acp-15-9593-2015, 2015.

Ban-Weiss, G. A. and Caldeira, K.: Geoengineering as an optimization problem, Environ. Res. Lett., 5, 031001, https://doi.org/10.1088/1748-9326/5/3/034009, 2010.

Boucher, O., Denvil, S., Caubel, A., and Foujols, M. A.: IPSL IPSL-CM6A-LR model output prepared for CMIP6 GeoMIP G1, Earth System Grid Federation, https://doi.org/10.22033/ESGF/CMIP6.5054, 2018a. 
Boucher, O., Denvil, S., Caubel, A., and Foujols, M. A.: IPSL IPSL-CM6A-LR model output prepared for CMIP6 CMIP abrupt-4xCO2, Earth System Grid Federation, https://doi.org/10.22033/ESGF/CMIP6.5109, 2018 b.

Boucher, O., Denvil, S., Caubel, A., and Foujols, M. A.: IPSL IPSL-CM6A-LR model output prepared for CMIP6 CMIP piControl, Earth System Grid Federation, https://doi.org/10.22033/ESGF/CMIP6.5251, 2018c.

Boucher, O., Servonnat, J., Albright, A. L., Aumont, O., Balkanski, Y., Bastrikov, V., Bekki, S., Bonnet, R., Bony, S., Bopp, L., Braconnot, P., Brockmann, P., Cadule, P., Caubel, A., Cheruy, F., Codron, F., Cozic, A., Cugnet, D., D’Andrea, F., Davini, P., de Lavergne, C., Denvil, S., Deshayes, J., Devilliers, M., Ducharne, A., Dufresne, J.-L., Dupont, E., Éthé, C., Fairhead, L., Falletti, L., Flavoni, S., Foujols, M.-A., Gardoll, S., Gastineau, G., Ghattas, J., Grandpeix, J.-Y., Guenet, B., Guez, L., Guilyardi, E., Guimberteau, M., Hauglustaine, D., Hourdin, F., Idelkadi, A., Joussaume, S., Kageyama, M., Khodri, M., Krinner, G., Lebas, N., Levavasseur, G., Lévy, C., Li, L., Lott, F., Lurton, T., Luyssaert, S., Madec, G., Madeleine, J.-B., Maignan, F., Marchand, M., Marti, O., Mellul, L., Meurdesoif, Y., Mignot, J., Musat, I., Ottlé, C., Peylin, P., Planton, Y., Polcher, J., Rio, C., Rochetin, N., Rousset, C., Sepulchre, P., Sima, A., Swingedouw, D., Thiéblemont, R., Traore, A. K., Vancoppenolle, M., Vial, J., Vialard, J., Viovy, N., and Vuichard, N.: Presentation and evaluation of the IPSL-CM6A-LR climate model, J. Adv. Model. Earth Sy., 12, e2019MS002010, https://doi.org/10.1029/2019MS002010, 2020.

Budyko, M. I.: Climatic Changes, American Geophysical Union, Washington, DC, 1977.

Cole, J. N., Swart, N. C., Kharin, V. V., Lazare, M., Scinocca, J. F., Gillett, N. P., Anstey, J., Arora, V., Christian, J. R., Jiao, Y., Lee, W. G., Majaess, F., Saenko, O. A., Seiler, C., Seinen, C., Shao, A., Solheim, L., von Salzen, K., Yang, D., Winter, B., and Sigmond, M.: CCCma CanESM5 model output prepared for CMIP6 GeoMIP G1, Earth System Grid Federation, https://doi.org/10.22033/ESGF/CMIP6.3158, 2019.

Collins, W. J., Bellouin, N., Doutriaux-Boucher, M., Gedney, N., Halloran, P., Hinton, T., Hughes, J., Jones, C. D., Joshi, M., Liddicoat, S., Martin, G., O’Connor, F., Rae, J., Senior, C., Sitch, S., Totterdell, I., Wiltshire, A., and Woodward, S.: Development and evaluation of an Earth-System model - HadGEM2, Geosci. Model Dev., 4, 1051-1075, https://doi.org/10.5194/gmd-4-10512011, 2011.

Crutzen, P. J.: Albedo enhancement by stratospheric sulfur injections: A contribution to resolve a policy dilemma?, Climatic Change, 77, 211-220, https://doi.org/10.1007/s10584-006-9101y, 2006.

Curry, C. L., Sillmann, J., Bronaugh, D., Alterskjær, K., Cole, J. N. S., Kravitz., B., Kristjánsson, J. E., Muri, H., Niemeier, U., Robock, A., and Tilmes, S.: A multimodel examination of climate extremes in an idealized geoengineering experiment, J. Geophys. Res., 119, 3900-3923, https://doi.org/10.1002/2013JD020648, 2014.

Danabasoglu, G.: NCAR CESM2-WACCM model output prepared for CMIP6 GeoMIP G1, Earth System Grid Federation, https://doi.org/10.22033/ESGF/CMIP6.10029, 2019a.
Danabasoglu, G.: NCAR CESM2-WACCM model output prepared for CMIP6 CMIP abrupt-4xCO2, Earth System Grid Federation, https://doi.org/10.22033/ESGF/CMIP6.10039, 2019 b.

Danabasoglu, G.: NCAR CESM2-WACCM-FV2 model output prepared for CMIP6 CMIP piControl, Earth System Grid Federation, https://doi.org/10.22033/ESGF/CMIP6.11302, 2019c.

Dufresne, J.-L., Foujols, M.-A., Denvil, S., Caubel, A., Marti, O., Aumont, O., Balkanski, Y., Bekki, S., Bellenger, H., Benshila, R., Bony, S., Bopp, L., Braconnot, P., Brockmann, P., Cadule, P., Cheruy, F., Codron, F., Cozic, A., Cugnet, D., de Noblet, N., Duvel, J.-P., Ethé, C., Fairhead, L., Fichefet, T., Flavoni, S., Friedlingstein, P., Grandpeix, J.-Y., Guez, L., Guilyardi, E., Hauglustaine, D., Hourdin, F., Idelkadi, A., Ghattas, J., Joussaume, S., Kageyama, M., Krinner, G., Labetoulle, S., Lahellec, A., Lefebvre, M.-P., Lefevre, F., Levy, C., Li, Z. X., Lloyd, J., Lott, F., Madec, G., Mancip, M., Marchand, M., Masson, S., Meurdesoif, Y., Mignot, J., Musat, I., Parouty, S., Polcher, J., Rio, C., Schulz, M., Swingedouw, D., Szopa, S., Talandier, C., Terray, P., Viovy, N., and Vuichard, N.: Climate change projections using the IPSL-CM5 Earth System Model: From CMIP3 to CMIP5, Clim. Dynam., 40, 2123-2165, https://doi.org/10.1007/s00382012-1636-1, 2013.

Eyring, V., Bony, S., Meehl, G. A., Senior, C. A., Stevens, B., Stouffer, R. J., and Taylor, K. E.: Overview of the Coupled Model Intercomparison Project Phase 6 (CMIP6) experimental design and organization, Geosci. Model Dev., 9, 1937-1958, https://doi.org/10.5194/gmd-9-1937-2016, 2016.

Flynn, C. M. and Mauritsen, T.: On the climate sensitivity and historical warming evolution in recent coupled model ensembles, Atmos. Chem. Phys., 20, 7829-7842, https://doi.org/10.5194/acp-20-7829-2020, 2020.

Gent, P. R., Danabasoglu, G., Donner, L. J., Holland, M. M., Hunke, E. C., Jayne, S. R., Lawrence, D. M., Neale, R. B., Rasch, P. J., Vertenstein, M., Worley, P. H., Yang, Z.-L., and Zhang, M.: The Community Climate System Model Version 4, J. Climate, 24, 4973-4991, https://doi.org/10.1175/2011JCLI4083.1, 2011.

Gertler, C. G., O'Gorman, P. A., Kravitz, B., Moore, J. C., Phipps, S. J., and Watanabe, S.: Weakening of the extratropical storm tracks in solar geoengineering scenarios, Geophys. Res. Lett., 47, e2020GL087348, https://doi.org/10.1029/2020GL087348, 2020.

Gettelman, A., Mills, M. J., Kinnison, D. E., Garcia, R. R., Smith, A. K., Marsh, D. R., Tilmes, S., Vitt, F., Bardeen, C. G., McInerny, J., Liu, H.-L., Solomon, S. C., Polvani, L. M., Emmons, L. K., Lamarque, J.-F., Richter, J. H., Glanville, A. S., Bacmeister, J. T., Phillips, A. S., Neale, R. B., Simpson, I. R., DuVivier, A. K., Hodzic, A., and Randel, W. J.: The Whole Atmosphere Community Climate Model Version 6 (WACCM6), J. Geophys. Res.-Atmos., 124, 12380-12403, https://doi.org/10.1029/2019JD030943, 2019.

Giorgetta, M. A., Jungclaus, J., Reick, C. H., Legutke, S., Bader, J., Böttinger, M., Brovkin, V., Crueger, T., Esch, M., Fieg, K., Glushak, K., Gayler, V., Haak, H., Hollweg, H.-D., Ilyina, T., Kinne, S., Kornblueh, L., Matei, D., Mauritsen, T., Mikolajewicz, U., Mueller, W., Notz, D., Pithan, F., Raddatz, T., Rast, S., Redler, R., Roeckner, E., Schmidt, H., Schnur, R., Segschneider, J., Six, K. D., Stockhause, M., Timmreck, C., Wegner, J., Widmann, H., Wieners, K.-H., Claussen, M., Marotzke, J., and Stevens, B.: Climate and carbon cycle changes from 1850 to 2100 in MPI-ESM simulations for the Coupled Model Intercom- 
parison Project Phase 5, J. Adv. Model. Earth Sy., 5, 572-597, https://doi.org/10.1002/jame.20038, 2013.

Glienke, S., Irvine, P. J., and Lawrence, M. G.: The impact of geoengineering on vegetation in experiment G1 of the GeoMIP, J. Geophys. Res., 120, 10196-10213, https://doi.org/10.1002/2015JD024202, 2015.

Gordon, C., Cooper, C., Senior, C. A., Banks, H., Gregory, J. M., Johns, T. C., Mitchell, J. F. B., and Wood, R. A.: The simulation of SST, sea ice extents and ocean heat transports in a version of the Hadley Centre coupled model without flux adjustments, Clim. Dynam., 16, 147-168, https://doi.org/10.1007/s003820050010, 2000.

Govindasamy, B. and Caldeira, K.: Geoengineering Earth's radiation balance to mitigate $\mathrm{CO}_{2}$-induced climate change, Geophys. Res. Lett., 27, 2141-2144, https://doi.org/10.1029/1999GL006086, 2000.

Guo, A., Moore, J. C., and Ji, D.: Tropical atmospheric circulation response to the G1 sunshade geoengineering radiative forcing experiment, Atmos. Chem. Phys., 18, 8689-8706, https://doi.org/10.5194/acp-18-8689-2018, 2018.

Hansen, J., Sato, M., Ruedy, R., Nazarenko, L., Lacis, A., Schmidt, G. A., Russell, G., Aleinov, I., Bauer, M., Bauer, S., Bell, N., Cairns, B., Canuto, V., Chandler, M., Cheng, Y., Del Genio, A., Faluvegi, G., Fleming, E., Friend, A., Hall, T., Jackman, C., Kelley, M., Kiang, N., Koch, D., Lean, J., Lerner, J., Lo, K., Menon, S., Miller, R., Minnis, P., Novakov, T., Oinas, V., Perlwitz, J., Perlwitz, J., Rind, D., Romanou, A., Shindell, D., Stone, P., Sun, S., Tausnev, N., Thresher, D., Wielicki, B., Wong, T., Yaho, M., and Zhang, S.: Efficacy of Climate Forcings, J. Geophys. Res., 110, D18104, https://doi.org/10.1029/2005JD005776, 2005.

Hazeleger, W., Wang, X., Severijns, C., Ştefănescu, S., Bintanja, R., Sterl, A., Wyser, K., Semmler, T., Yang, S., van den Hurk, B., van Noije, T., van der Linden, E., and van der Wiel, K.: EC-Earth V2.2: Description and validation of a new seamless Earth system prediction model, Clim. Dynam., 39, 2611-2629, https://doi.org/10.1007/s00382-011-1228-5, 2011.

Hourdin, F., Foujols, M.-A., Codron, F., Guemas, V., Dufresne, J.L., Bony, S., Denvil, S., Guez, L., Lott, F., Ghattas, J., Braconnot, P., Marti, O., Meurdesoif, Y., and Bopp, L.: Impact of the LMDZ atmospheric grid configuration on the climate and sensitivity of the IPSL-CM5A coupled model, Clim. Dynam., 40, 2167-2192, https://doi.org/10.1007/s00382-012-1411-3, 2012.

Hurrell, J. W., Holland, M. M., Gent, P. R., Ghan, S., Kay, J. E., Kushner, P. J., Lamarque, J.-F., Large, W. G., Lawrence, D., Lindsay, K., Lipscomb, W. H., Long, M. C., Mahowald, N., Marsh, D. R., Neale, R. B., Rasch, P., Vavrus, S., Vertenstein, M., Bader, D., Collins, W. D., Hack, J. J., Kiehl, J., and Marshall, S.: The Community Earth System Model: A Framework for Collaborative Research, B. Am. Meteorol. Soc., 94, 13391360, https://doi.org/10.1175/BAMS-D-12-00121.1, 2013.

Irvine, P., Emmanuel, K., He, J., Horowitz, L. W., Vecchi, G., and Keith, D.: Halving warming with idealized solar geoengineering moderates key climate hazards, Nat. Clim. Change, 9, 295-299, 2019.

Irvine, P. J., Kravitz, B., Lawrence, M. G., and Muri, H.: An overview of the Earth system science of solar geoengineering, WIREs Climate Change, 7, 815-833, https://doi.org/10.1002/wcc.423, 2016.
Ji, D., Wang, L., Feng, J., Wu, Q., Cheng, H., Zhang, Q., Yang, J., Dong, W., Dai, Y., Gong, D., Zhang, R.-H., Wang, X., Liu, J., Moore, J. C., Chen, D., and Zhou, M.: Description and basic evaluation of Beijing Normal University Earth System Model (BNU-ESM) version 1, Geosci. Model Dev., 7, 2039-2064, https://doi.org/10.5194/gmd-7-2039-2014, 2014.

Jones, A.: MOHC UKESM1.0-LL model output prepared for CMIP6 GeoMIP G1, Earth System Grid Federation, https://doi.org/10.22033/ESGF/CMIP6.5812, 2019.

Jones, A., Haywood, J. M., Alterskjær, K., Boucher, O., Cole, J. N. S., Curry, C. L., Irvine, P. J., Ji, D., Kravitz, B., Moore, J. E. K. J. C., Niemeier, U., Robock, A., Schmidt, H., Singh, B., Tilmes, S., Watanabe, S., and Yoon, J.-H.: The impact of abrupt suspension of solar radiation management (termination effect) in experiment G2 of the Geoengineering Model Intercomparison Project (GeoMIP), J. Geophys. Res.-Atmos., 118, 9743-9752, https://doi.org/10.1002/jgrd.50762, 2013.

Jones, A., Haywood, J. M., Jones, A. C., Tilmes, S., Kravitz, B., and Robock, A.: North Atlantic Oscillation response in GeoMIP experiments G6solar and G6sulfur: why detailed modelling is needed for understanding regional implications of solar radiation management, Atmos. Chem. Phys., 21, 1287-1304, https://doi.org/10.5194/acp-21-1287-2021, 2021.

Kalidindi, S., Bala, G., Modak, A., and Caldeira, K.: Modeling of solar radiation management: A comparison of simulations using reduced solar constant and stratospheric sulfate aerosols, Clim. Dynam., 44, 2909-2925, https://doi.org/10.1007/s00382014-2240-3, 2015.

Kelley, M., Schmidt, G. A., Nazarenko, L. S., Bauer, S. E., Ruedy, R., Russell, G. L., Ackerman, A. S., Aleinov, I., Bauer, M., Bleck, R., Canuto, V., Cesana, G., Cheng, Y., Clune, T. L., Cook, B. I., Cruz, C. A., Del Genio, A. D., Elsaesser, G. S., Faluvegi, G., Kiang, N. Y., Kim, D., Lacis, A. A., Leboissetier, A., LeGrande, A. N., Lo, K. K., Marshall, J., Matthews, E. E., McDermid, S., Mezuman, K., Miller, R. L., Murray, L. T., Oinas, V., Orbe, C., Pérez García-Pando, C., Perlwitz, J. P., Puma, M. J., Rind, D., Romanou, A., Shindell, D. T., Sun, S., Tausnev, N., Tsigaridis, K., Tselioudis, G., Weng, E., Wu, J., and Yao, M.-S.: GISS-E2.1: Configurations and Climatology, J. Adv. Model. Earth Sy., 12, e2019MS002025, https://doi.org/10.1029/2019MS002025, 2020.

Kirkevåg, A., Iversen, T., Seland, Ø., Hoose, C., Kristjánsson, J. E., Struthers, H., Ekman, A. M. L., Ghan, S., Griesfeller, J., Nilsson, E. D., and Schulz, M.: Aerosol-climate interactions in the Norwegian Earth System Model - NorESM1-M, Geosci. Model Dev., 6, 207-244, https://doi.org/10.5194/gmd-6207-2013, 2013.

Knutti, R., Masson, D., and Gettelman, A.: Climate model genealogy: Generation CMIP5 and how we got there, Geophys. Res. Lett., 40, 1194-1199, https://doi.org/10.1002/grl.50256, 2013.

Kravitz, B., Robock, A., Boucher, O., Schmidt, H., Taylor, K. E., Stenchikov, G., and Schulz, M.: The Geoengineering Model Intercomparison Project (GeoMIP), Atmos. Sci. Lett., 12, 162167, https://doi.org/10.1002/asl.316, 2011.

Kravitz, B., Caldeira, K., Boucher, O., Robock, A., Rasch, P. J., Alterskjær, K., Karam, D. B., Cole, J. N. S., Curry, C. L., Haywood, J. M., Irvine, P. J., Ji, D., Jones, A., Kristjánsson, J. E., Lunt, D. J., Moore, J., Niemeier, U., Schmidt, H., Schulz, M., Singh, B., Tilmes, S., Watanabe, S., Yang, S., and Yoon, J.-H.: Cli- 
mate model response from the Geoengineering Model Intercomparison Project (GeoMIP), J. Geophys. Res., 118, 8320-8332, https://doi.org/10.1002/jgrd.50646, 2013a.

Kravitz, B., Rasch, P. J., Forster, P. M., Andrews, T., Cole, J. N. S., Irvine, P. J., Ji, D., Kristjánsson, J. E., Moore, J. C., Muri, H., Niemeier, U., Robock, A., Singh, B., Tilmes, S., Watanabe, S., and Yoon, J.-H.: An energetic perspective on hydrological cycle changes in the Geoengineering Model Intercomparison Project (GeoMIP), J. Geophys. Res., 118, 13087-13102, https://doi.org/10.1002/2013JD020502, 2013b.

Kravitz, B., MacMartin, D. G., Robock, A., Rasch, P. J., Ricke, K. L., Cole, J. N. S., Curry, C. L., Irvine, P. J., Ji, D., Keith, D. W., Kristjánsson, J. E., Moore, J. C., Muri, H., Singh, B., Tilmes, S., Watanabe, S., Yang, S., and Yoon, J.-H.: A multi-model assessment of regional climate disparities caused by solar geoengineering, Environ. Res. Lett., 9, 074013, https://doi.org/10.1088/17489326/9/7/074013, 2014.

Kravitz, B., Robock, A., Tilmes, S., Boucher, O., English, J. M., Irvine, P. J., Jones, A., Lawrence, M. G., MacCracken, M., Muri, H., Moore, J. C., Niemeier, U., Phipps, S. J., Sillmann, J., Storelvmo, T., Wang, H., and Watanabe, S.: The Geoengineering Model Intercomparison Project Phase 6 (GeoMIP6): simulation design and preliminary results, Geosci. Model Dev., 8, 33793392, https://doi.org/10.5194/gmd-8-3379-2015, 2015.

Kravitz, B., MacMartin, D. G., Wang, H., and Rasch, P. J.: Geoengineering as a design problem, Earth Syst. Dynam., 7, 469-497, https://doi.org/10.5194/esd-7-469-2016, 2016.

Kravitz, B., MacMartin, D. G., Mills, M. J., Richter, J. H., Tilmes, S., Lamarque, J., Tribbia, J. J., and Vitt, F.: First Simulations of Designing Stratospheric Sulfate Aerosol Geoengineering to Meet Multiple Simultaneous Climate Objectives, J. Geophys. Res., 122, 12616-12634, https://doi.org/10.1002/2017JD026874, 2017

Kravitz, B., MacMartin, D. G., Tilmes, S., Richter, J. H., Mills, M. J., Cheng, W., Dagon, K., Glanville, A. S., Lamarque, J.-F., Simpson, I., Tribbia, J., and Vitt, F.: Comparing surface and stratospheric impacts of geoengineering with different $\mathrm{SO}_{2}$ injection strategies, J. Geophys. Res., 124, 7900-7918, https://doi.org/10.1029/2019JD030329, 2019.

Lawrence Livermore National Laboratory: ESGF@DOE/LLNL, available at: https://esgf-node.llnl.gov/projects/esgf-1lnl/, last access: 17 March 2021.

Lurton, T., Balkanski, Y., Bastrikov, V., Bekki, S., Bopp, L., Braconnot, P., Brockmann, P., Cadule, P., Contoux, C., Cozic, A., Cugnet, D., Dufresne, J.-L., Éthé, C., Foujols, M.-A., Ghattas, J., Hauglustaine, D., Hu, R.-M., Kageyama, M., Khodri, M., Lebas, N., Levavasseur, G., Marchand, M., Ottlé, C., Peylin, P., Sima, A., Szopa, S., Thiéblemont, R., Vuichard, N., and Boucher, O.: Implementation of the CMIP6 Forcing Data in the IPSL-CM6ALR Model, J. Adv. Model. Earth Sy., 12, e2019MS001940, https://doi.org/10.1029/2019MS001940, 2020.

MacMartin, D. G., Keith, D. W., Kravitz, B., and Caldeira, K.: Management of trade-offs in geoengineering through optimal choice of non-uniform radiative forcing, Nat. Clim. Change, 3, 365-368, https://doi.org/10.1038/nclimate1722, 2013.

Madronich, S., Tilmes, S., Kravitz, B., MacMartin, D. G., and Richter, J. H.: Response of surface ultraviolet and visible radiation to stratospheric $\mathrm{SO}_{2}$ injection, Atmosphere, 9, 432, https://doi.org/10.3390/atmos9110432, 2018.
Mauritsen, T., Bader, J., Becker, T., Behrens, J., Bittner, M., Brokopf, R., Brovkin, V., Claussen, M., Crueger, T., Esch, M., Fast, I., Fiedler, S., Fläschner, D., Gayler, V., Giorgetta, M., Goll, D. S., Haak, H., Hagemann, S., Hedemann, C., Hohenegger, C., Ilyina, T., Jahns, T., Jimenéz-de-la Cuesta, D., Jungclaus, J., Kleinen, T., Kloster, S., Kracher, D., Kinne, S., Kleberg, D., Lasslop, G., Kornblueh, L., Marotzke, J., Matei, D., Meraner, K., Mikolajewicz, U., Modali, K., Möbis, B., Müller, W. A., Nabel, J. E. M. S., Nam, C. C. W., Notz, D., Nyawira, S.-S., Paulsen, H., Peters, K., Pincus, R., Pohlmann, H., Pongratz, J., Popp, M., Raddatz, T. J., Rast, S., Redler, R., Reick, C. H., Rohrschneider, T., Schemann, V., Schmidt, H., Schnur, R., Schulzweida, U., Six, K. D., Stein, L., Stemmler, I., Stevens, B., von Storch, J.S., Tian, F., Voigt, A., Vrese, P., Wieners, K.-H., Wilkenskjeld, S., Winkler, A., and Roeckner, E.: Developments in the MPIM Earth System Model version 1.2 (MPI-ESM1.2) and Its Response to Increasing $\mathrm{CO}_{2}$, J. Adv. Model. Earth Sy., 11, 9981038, https://doi.org/10.1029/2018MS001400, 2019.

Meehl, G. A., Senior, C. A., Eyring, V., Flato, G., Lamarque, J.-F., Stouffer, R. J., Taylor, K. E., and Schlund, M.: Context for interpreting equilibrium climate sensitivity and transient climate response from the CMIP6 Earth system models, Sci. Adv., 6, eaba1981, https://doi.org/10.1126/sciadv.aba1981, 2020.

Moore, J. C., Rinke, A., Yu, X., Ji, D., Cui, X., Li, Y., Alterskjær, K., Kristjánsson, J. E., Boucher, O., Huneeus, N., Kravitz, B., Robock, A., Niemeier, U., Schmidt, H., Schulz, M., Tilmes, S., and Watanabe, S.: Arctic sea ice and atmospheric circulation under the GeoMIP G1 scenario, J. Geophys. Res., 119, 567-583, https://doi.org/10.1002/2013JD021060, 2014.

Moreno-Cruz, J. B., Ricke, K. L., and Keith, D. W.: A simple model to account for regional inequalities in the effectiveness of solar radiation management, Climatic Change, 110, 649-668, 2012.

NASA Goddard Institute for Space Studies (NASA/GISS): NASA-GISS GISS-E2.1G model output prepared for CMIP6 CMIP abrupt-4xCO2, Earth System Grid Federation, https://doi.org/10.22033/ESGF/CMIP6.6976, 2018.

NASA Goddard Institute for Space Studies (NASA/GISS): NASA-GISS GISS-E2-1-G-CC model output prepared for CMIP6 CMIP piControl, Earth System Grid Federation, https://doi.org/10.22033/ESGF/CMIP6.11856, 2019.

Neale, R. B., Chen, C., Gettelman, A., Lauritzen, P., Park, S., Williamson, D., Conley, A., Garcia, R., Kinnison, D., and Lamarque, J.: Description of the NCAR community atmosphere model (CAM 5.0), Tech. rep., National Center for Atmospheric Research, Boulder, Colorado, 2010.

Niemeier, U., Schmidt, H., Alterskjær, K., and Kristjánsson, J. E.: Solar irradiance reduction via climate engineering: Impact of different techniques on the energy balance and the hydrological cycle, J. Geophys. Res., 118, 11905-11917, https://doi.org/10.1002/2013JD020445, 2013.

NRC: Climate Intervention: Reflecting Sunlight to Cool Earth, Tech. rep., National Research Council, available at: http://www.nap.edu/catalog/18988/ climate-intervention-reflecting-sunlight-to-cool-earth, last access: 7 May 2015.

Phipps, S. J., Rotstayn, L. D., Gordon, H. B., Roberts, J. L., Hirst, A. C., and Budd, W. F.: The CSIRO Mk3L climate system model version 1.0 - Part 1: Description and evaluation, 
Geosci. Model Dev., 4, 483-509, https://doi.org/10.5194/gmd-4483-2011, 2011.

Phipps, S. J., Rotstayn, L. D., Gordon, H. B., Roberts, J. L., Hirst, A. C., and Budd, W. F.: The CSIRO Mk3L climate system model version 1.0 - Part 2: Response to external forcings, Geosci. Model Dev., 5, 649-682, https://doi.org/10.5194/gmd-5649-2012, 2012.

Pitari, G., Aquila, V., Kravitz, B., Robock, A., Watanabe, S., Cionni, I., Luca, N. D., di Genova, G., Mancini, E., and Tilmes, S.: Stratospheric ozone response to sulfate geoengineering: Results from the Geoengineering Model Intercomparison Project (GeoMIP), J. Geophys. Res., 119, 2629-2653, 2014.

Richter, J. H., Tilmes, S., Mills, M. J., Tribbia, J. J., Kravitz, B., MacMartin, D. G., Vitt, F., and Lamarque, J.: Stratospheric Dynamical Response and Ozone Feedbacks in the Presence of $\mathrm{SO}_{2}$ Injections, J. Geophys. Res., 122, 12557-12573, https://doi.org/10.1002/2017JD026912, 2017.

Ricke, K. L., Morgan, M. G., and Allen, M. R.: Regional climate response to solar-radiation management, Nat. Geosci., 3, 537541, https://doi.org/10.1038/ngeo915, 2010.

Robock, A.: Volcanic eruptions and climate, Rev. Geophys., 38, 191-219, https://doi.org/10.1029/1998RG000054, 2000.

Robock, A., MacMartin, D. G., Duren, R., and Christensen, M. W.: Studying geoengineering with natural and anthropogenic analogs, Climatic Change, 121, 445-458, https://doi.org/10.1007/s10584-013-0777-5, 2013.

Russotto, R. D. and Ackerman, T. P.: Changes in clouds and thermodynamics under solar geoengineering and implications for required solar reduction, Atmos. Chem. Phys., 18, 11905-11925, https://doi.org/10.5194/acp-18-11905-2018, 2018.

Schmidt, G. A., Kelley, M., Nazarenko, L., Ruedy, R., Russell, G. L., Aleinov, I., Bauer, M., Bauer, S. E., Bhat, M. K., Bleck, R., Canuto, V., Chen, Y.-H., Cheng, Y., Clune, T. L., Genio, A. D., de Fainchtein, R., Faluvegi, G., Hansen, J. E., Healy, R. J., Kiang, N. Y., Koch, D., Lacis, A. A., LeGrande, A. N., Lerner, J., Lo, K. K., Matthews, E. E., Menon, S., Miller, R. L., Oinas, V., Oloso, A. O., Perlwitz, J. P., Puma, M. J., Putman, W. M., Rind, D., Romanou, A., Sato, M., Shindell, D. T., Sun, S., Syed, R. A., Tausnev, N., Tsigaridis, K., Under, N., Volugarakis, A., Yao, M.S., and Zhang, J.: Configuration and assessment of the GISS ModelE2 contributions to the CMIP5 archive, J. Adv. Modell. Earth Sy., 6, 141-184, https://doi.org/10.1002/2013MS000265, 2014.

Séférian, R.: CNRM-CERFACS CNRM-ESM2-1 model output prepared for CMIP6 CMIP abrupt-4xCO2, Earth System Grid Federation, https://doi.org/10.22033/ESGF/CMIP6.3918, 2018a.

Séférian, R.: CNRM-CERFACS CNRM-ESM2-1 model output prepared for CMIP6 CMIP piControl, Earth System Grid Federation, https://doi.org/10.22033/ESGF/CMIP6.4165, 2018b.

Séférian, R.: CNRM-CERFACS CNRM-ESM2-1 model output prepared for CMIP6 CMIP G1, Earth System Grid Federation, https://doi.org/10.22033/ESGF/CMIP6.3902, 2018c.

Séférian, R., Nabat, P., Michou, M., Saint-Martin, D., Voldoire, A., Colin, J., Decharme, B., Delire, C., Berthet, S., Chevallier, M., Sénési, S., Franchisteguy, L., Vial, J., Mallet, M., Joetzjer, E., Geoffroy, O., Guérémy, J.-F., Moine, M.-P., Msadek, R., Ribes, A., Rocher, M., Roehrig, R., Salas-y Mélia, D., Sanchez, E., Terray, L., Valcke, S., Waldman, R., Aumont, O., Bopp, L., Deshayes, J., Éthé, C., and Madec, G.: Evaluation of CNRM Earth Sys- tem Model, CNRM-ESM2-1: Role of Earth System Processes in Present-Day and Future Climate, J. Adv. Model. Earth Sy., 11, 4182-4227, https://doi.org/10.1029/2019MS001791, 2019.

Sellar, A. A., Jones, C. G., Mulcahy, J. P., Tang, Y., Yool, A., Wiltshire, A., O’Connor, F. M., Stringer, M., Hill, R., Palmieri, J., Woodward, S., de Mora, L., Kuhlbrodt, T., Rumbold, S. T., Kelley, D. I., Ellis, R., Johnson, C. E., Walton, J., Abraham, N. L., Andrews, M. B., Andrews, T., Archibald, A. T., Berthou, S., Burke, E., Blockley, E., Carslaw, K., Dalvi, M., Edwards, J., Folberth, G. A., Gedney, N., Griffiths, P. T., Harper, A. B., Hendry, M. A., Hewitt, A. J., Johnson, B., Jones, A., Jones, C. D., Keeble, J., Liddicoat, S., Morgenstern, O., Parker, R. J., Predoi, V., Robertson, E., Siahaan, A., Smith, R. S., Swaminathan, R., Woodhouse, M. T., Zeng, G., and Zerroukat, M.: UKESM1: Description and Evaluation of the U.K. Earth System Model, J. Adv. Model. Earth Sy., 11, 4513-4558, https://doi.org/10.1029/2019MS001739, 2019.

Simpson, I., Tilmes, S., Richter, J., Kravitz, B., MacMartin, D., Mills, M., Fasullo, J., and Pendergrass, A.: The regional hydroclimate response to stratospheric sulfate geoengineering and the role of stratospheric heating, J. Geophys. Res., 124, 1258712616, https://doi.org/10.1029/2019JD031093, 2019.

Stevens, B., Giorgetta, M., Esch, M., Mauritsen, T., Crueger, T., Rast, S., Salzmann, M., Schmidt, H., Bader, J., Block, K., Brokopf, R., Fast, I., Kinne, S., Kornblueh, L., Lohmann, U., Pincus, R., Reichler, T., and Roeckner, E.: Atmospheric component of the MPI-M Earth System Model: ECHAM6, J. Adv. Model. Earth Sy., 5, 146-172, https://doi.org/10.1002/jame.20015, 2013.

Swart, N. C., Cole, J. N., Kharin, V. V., Lazare, M., Scinocca, J. F., Gillett, N. P., Anstey, J., Arora, V., Christian, J. R., Jiao, Y., Lee, W. G., Majaess, F., Saenko, O. A., Seiler, C., Seinen, C., Shao, A., Solheim, L., von Salzen, K., Yang, D., Winter, B., and Sigmond, M.: CCCma CanESM5 model output prepared for CMIP6 CMIP piControl, Earth System Grid Federation, https://doi.org/10.22033/ESGF/CMIP6.3673, 2019a.

Swart, N. C., Cole, J. N., Kharin, V. V., Lazare, M., Scinocca, J. F., Gillett, N. P., Anstey, J., Arora, V., Christian, J. R., Jiao, Y., Lee, W. G., Majaess, F., Saenko, O. A., Seiler, C., Seinen, C., Shao, A., Solheim, L., von Salzen, K., Yang, D., Winter, B., and Sigmond, M.: CCCma CanESM5 model output prepared for CMIP6 CMIP abrupt-4xCO2, Earth System Grid Federation, https://doi.org/10.22033/ESGF/CMIP6.3532, 2019b.

Swart, N. C., Cole, J. N. S., Kharin, V. V., Lazare, M., Scinocca, J. F., Gillett, N. P., Anstey, J., Arora, V., Christian, J. R., Hanna, S., Jiao, Y., Lee, W. G., Majaess, F., Saenko, O. A., Seiler, C., Seinen, C., Shao, A., Sigmond, M., Solheim, L., von Salzen, K., Yang, D., and Winter, B.: The Canadian Earth System Model version 5 (CanESM5.0.3), Geoscientific Model Development, 12 4823-4873, https://doi.org/10.5194/gmd-12-4823-2019, 2019c.

Tang, Y., Rumbold, S., Ellis, R., Kelley, D., Mulcahy, J., Sellar, A., Walton, J., and Jones, C.: MOHC UKESM1.0-LL model output prepared for CMIP6 CMIP abrupt-4xCO2, Earth System Grid Federation, https://doi.org/10.22033/ESGF/CMIP6.5843, 2019a.

Tang, Y., Rumbold, S., Ellis, R., Kelley, D., Mulcahy, J., Sellar, A., Walton, J., and Jones, C.: MOHC UKESM1.0-LL model output prepared for CMIP6 CMIP piControl, Earth System Grid Federation, https://doi.org/10.22033/ESGF/CMIP6.6298, 2019b. 
Taylor, K. E., Stouffer, R. J., and Meehl, G. A.: An overview of CMIP5 and the experiment design, B. Am. Meteorol. Soc., 93, 485-498, https://doi.org/10.1175/BAMS-D-11-00094.1, 2012.

Tilmes, S., Fasullo, J., Lamarque, J.-F., Marsh, D. R., Mills, M., Alterskjær, K., Muri, H., Kristjánsson, J. E., Boucher, O., Schulz, M., Cole, J. N. S., Curry, C. L., Jones, A., Haywood, J., Irvine, P. J., Ji, D., Moore, J. C., Karam, D. B., Kravitz, B., Rasch, P. J., Singh, B., Yoon, J.-H., Niemeier, U., Schmidt, H., Robock, A., Yang, S., and Watanabe, S.: The hydrological impact of geoengineering in the Geoengineering Model Intercomparison Project (GeoMIP), J. Geophys. Res., 118, 11036-11058, https://doi.org/10.1002/jgrd.50868, 2013.

Tilmes, S., Richter, J. H., Mills, M. J., Kravitz, B., MacMartin, D. G., Garcia, R. R., Kinnison, D. E., Lamarque, J.-F., Tribbia, J., and Vitt, F.: Effects of Different Stratospheric $\mathrm{SO}_{2}$ Injection Altitudes on Stratospheric Chemistry and Dynamics, J. Geophys. Res., 123, 4654-4673, https://doi.org/10.1002/2017JD028146, 2018.

Vial, J., Dufresne, J.-L., and Bony, S.: On the interpretation of intermodel spread in CMIP5 climate sensitivity estimates, Clim. Dynam., 41, 3339-3362, https://doi.org/10.1007/s00382-013-17259, 2013.

Vignesh, P. P., Jiang, J. H., Kishore, P., Su, H., Smay, T., Brighton, N., and Velicogna, I.: Assessment of CMIP6 cloud fraction and comparison with satellite observations, Earth Space Sci., 7, e2019EA000975, https://doi.org/10.1029/2019EA000975, 2020.

Visioni, D., MacMartin, D. G., Kravitz, B., Tilmes, S., Mills, M. J., Richter, J. H., and Boudreau, M. P.: Seasonal injection strategies for stratospheric aerosol geoengineering, Geophys. Res. Lett., 46, 7790-7799, https://doi.org/10.1029/2019GL083680, 2019.

Watanabe, S., Miura, H., Sekiguchi, M., Nagashima, T., Sudo, K., Emori, S., and Kawamiya, M.: Development of an atmospheric general circulation model for integrated Earth system modeling on the Earth Simulator, J. Earth Simulator, 9, 27-35, 2008.

Watanabe, S., Hajima, T., Sudo, K., Nagashima, T., Takemura, T., Okajima, H., Nozawa, T., Kawase, H., Abe, M., Yokohata, T., Ise, T., Sato, H., Kato, E., Takata, K., Emori, S., and Kawamiya, M.: MIROC-ESM 2010: model description and basic results of CMIP5-20c3m experiments, Geosci. Model Dev., 4, 845-872, https://doi.org/10.5194/gmd-4-845-2011, 2011.
Wieners, K.-H., Giorgetta, M., Jungclaus, J., Reick, C., Esch, M., Bittner, M., Legutke, S., Schupfner, M., Wachsmann, F., Gayler, V., Haak, H., de Vrese, P., Raddatz, T., Mauritsen, T., von Storch, J.-S., Behrens, J., Brovkin, V., Claussen, M., Crueger, T., Fast, I., Fiedler, S., Hagemann, S., Hohenegger, C., Jahns, T., Kloster, S., Kinne, S., Lasslop, G., Kornblueh, L., Marotzke, J., Matei, D., Meraner, K., Mikolajewicz, U., Modali, K., Müller, W., Nabel, J., Notz, D., Peters, K., Pincus, R., Pohlmann, H., Pongratz, J., Rast, S., Schmidt, H., Schnur, R., Schulzweida, U., Six, K., Stevens, B., Voigt, A., and Roeckner, E.: MPI-M MPI-ESM1.2-LR model output prepared for CMIP6 CMIP piControl, Earth System Grid Federation, https://doi.org/10.22033/ESGF/CMIP6.6675, 2019a.

Wieners, K.-H., Giorgetta, M., Jungclaus, J., Reick, C., Esch, M., Bittner, M., Legutke, S., Schupfner, M., Wachsmann, F., Gayler, V., Haak, H., de Vrese, P., Raddatz, T., Mauritsen, T., von Storch, J.-S., Behrens, J., Brovkin, V., Claussen, M., Crueger, T., Fast, I., Fiedler, S., Hagemann, S., Hohenegger, C., Jahns, T., Kloster, S., Kinne, S., Lasslop, G., Kornblueh, L., Marotzke, J., Matei, D., Meraner, K., Mikolajewicz, U., Modali, K., Müller, W., Nabel, J., Notz, D., Peters, K., Pincus, R., Pohlmann, H., Pongratz, J., Rast, S., Schmidt, H., Schnur, R., Schulzweida, U., Six, K., Stevens, B., Voigt, A., and Roeckner, E.: MPI-M MPI-ESM1.2-LR model output prepared for CMIP6 CMIP abrupt-4xCO2, Earth System Grid Federation, https://doi.org/10.22033/ESGF/CMIP6.6459, 2019b.

Xia, L., Robock, A., Cole, J. N. S., Curry, C. L., Ji, D., Jones, A., Kravitz, B., Moore, J. C., Muri, H., Niemeier, U., Singh, B., Tilmes, S., Watanabe, S., and Yoon, J.-H.: Solar Radiation Management impacts on agriculture in China: A case study in the Geoengineering Model Intercomparison Project (GeoMIP), J. Geophys. Res., 119, 8695-8711, https://doi.org/10.1002/2013JD020630, 2014.

Zelinka, M. D., Myers, T. A., McCoy, D. T., Po-Chedley, S., Caldwell, P. M., Ceppi, P., Klein, S. A., and Taylor, K. E.: Causes of higher climate sensitivity in CMIP6 models, Geophys. Res. Lett., 47, e2019GL085782, https://doi.org/10.1029/2019GL085782, 2020 . 